Published in "Journal of Sedimentary Research 85(6): 660-682, 2015"

which should be cited to refer to this work.

\title{
ORIGIN OF MICROPORES IN LATE JURASSIC (OXFORDIAN) MICRITES OF THE EASTERN PARIS BASIN, FRANCE
}

\author{
CÉDRIC CARPENTIER, ${ }^{1}$ SERGE FERRY,${ }^{2}$ CHRISTOPHE LÉCUYER,${ }^{3}$ ANDRÉ STRASSER,${ }^{4}$ YVES GÉRAUD,${ }^{1}$ AND ALAIN \\ TROUILLER ${ }^{5}$ \\ ${ }^{1}$ Université de Lorraine, CNRS, CREGU, GeoRessources Lab, Faculté des Sciences et Technologies, BP 70239, F-54506, Vandoeuvre-lès-Nancy, France \\ ${ }^{2}$ Retired from the University of Lyon, France \\ ${ }^{3}$ UMR, 5276 LGLTPE Bâtiment Géode, 2 Rue Raphaël Dubois, 69622 Villeurbanne Cedex, France, and Institut Universitaire de France \\ ${ }^{4}$ Department of Geosciences, University of Fribourg, CH-1700 Fribourg, Switzerland \\ ${ }^{5}$ ANDRA, $1 / 7$ rue Jean Monnet, F-92290 Châtenay-Malabry cedex, France \\ e-mail: cedric.carpentier@univ-lorraine.f
}

\begin{abstract}
Porous micritic facies, either primary chalks or resulting from secondary destructive micritization, can constitute important hydrocarbon or water reservoirs. Characterization of reservoir properties and the understanding of factors which controlled the distribution of porosity are of primary interest to evaluate the prospective reserves. Middle and late Oxfordian limestones of the eastern Paris Basin show several horizons with porosities higher than $20 \%$. The porosity is mainly microporous and located either within secondary micritized grains or in the micritic matrix. Using SEM, cathodoluminescence, as well as confocal microscopy, stable oxygen and carbon isotope ratios, and petrophysical measurements, a scenario for the evolution of the micropores is proposed. Lime mudstones to packstones constitute the majority of the high-porosity facies (HPFs). Inner lagoonal deposits are more micritized and thus more porous than grainstones, and facies rich in leiolitic oncoids and echinoid clasts are less impacted by micritization. Micritization was responsible for an increase of the intragranular porosity in most grain types. During both eogenesis and shallow burial, mineralogical stabilization dissolved aragonitic particles and allowed precipitation of calcite rhombs. This process was probably enhanced below surfaces of subaerial exposure. During burial, Ostwald ripening allowed the growth of larger micrite crystals at the expense of smaller ones during early Berriasian and late Aptian recharges of deep aquifers when the northern margin of the basin was exposed. Overgrowths on micrite crystals were more important in intervals strongly affected by chemical compaction, which favored oversaturation of waters with respect to calcite. In low-porosity horizons (LPFs), the dense micritic texture of oncoids and the monocrystalline architecture of echinoid clasts prevented an intense micritization, while the strong chemical compaction enhanced poronecrosis. Telogenetic fracturing created new fluid pathways that favored inputs of meteoric fluid in porous micrite and allowed the continuation of Ostwald ripening during Cenozoic times. As a whole, mesogenetic inputs of waters undersaturated with respect to calcite in deep aquifers during exposure of basin margins are a more efficient process than early subaerial exposure for enhancing aggrading neomorphism and appearance of microporous micrites. Initial mineralogical heterogeneities also impact the intensity of chemical compaction and thus the stratigraphical distribution of microporous limestones.
\end{abstract}

\section{INTRODUCTION}

Organic buildups, dolomitic, fractured, or granular facies are commonly considered as most suitable for the formation of porous and permeable reservoirs in carbonate environments (Derby and Kilpatrick 1985; Mc Quillan 1985; Saller and Moore 1986; Greenlee and Lehrmann 1993; Cavallo and Smosna 1997; Kenter et al. 2006). However, some hydrocarbon reservoirs occur in micritic facies (Moshier 1989a; Lambert et al. 2006). Chalky micritic sediments deposited in environments from shallow peritidal platform to an offshore basin can contain high porosities corresponding essentially to microporosity (Hairabian et al. 2013; Moshier 1989b; Richard et al. 2007). These facies are different from classical coccolith chalks and were initially composed of lime muds. Various processes have been proposed to explain the development or the preservation of microporosity in lime muds. The original mineralogy (aragonite vs. magnesian calcite), which controls the intensity of early mineralogical stabilization and thus the intensity of early cementation and poronecrosis, is considered to be a major control on the formation of microporous reservoirs (Volery et al. 2009a, 2010). Coeval dissolution and aggradation of micrite crystals in water undersaturated with respect to calcite have also been evoked to explain microporosity preservation and enhancement (Lasemi and Sandberg 1984; Moshier 1989b). However, different models for the timing of aggradation have been proposed in the literature. Although Steinen (1978) argued that aggradation of micrites is efficient mainly during burial, Richard et al. (2007) interpreted the microporosity of the late Barremian and middle Aptian Urgonian Limestone of the Jura and Bas Dauphiné platform as the result of preservation of initial porosity and inhibition of mesogenetic compaction due to aggradational processes and Ostwald ripening in the meteoric phreatic lens during late eogenesis. Several authors have proposed that early meteoric diagenesis below surfaces of subaerial exposure is the main 
factor controlling the appearance of porous micrites on a shallow carbonate platform (Deville de Periere et al. 2011; Volery et al. 2010). However, such a scenario is difficult to consider for microporous muds deposited in deep offshore environments such as the Cenomanian and Maastrichtian "Scaglia" limestones of southeast Italy (Hairabian et al. 2013) or the Late Cretaceous carbonate turbidites of the Mid-Pacific Mountains (Ferry and Schaaf 1981). In contrast, Leonide et al. (2014) proposed that early meteoric eogenesis was responsible for the entire closure of primary porosity in the inner-carbonate-platform muds of the Barremian and Aptian in southeast France. These authors envisioned that porosity enhancement was mainly due to Ostwald ripening during early burial and to dissolution by meteoric fluids during telogenesis. Dissolution by reactive aqueous fluids during burial is another scenario proposed to explain microporosity in lagoonal muds of the Cretaceous Mishrif Formation (Lambert et al. 2006). Since carbonate muds are able to provide important gas or water reservoirs, the creation of models of microporosity evolution during diagenesis to predict the distribution of porous facies is of great interest. In this context, the understanding of the impact of primary sedimentary factors and secondary diagenetic processes is essential. The challenge is to distinguish effects of early diagenesis, which are often evoked, from late evolution of the microporosity during mesogenesis or telogenesis, which are often neglected.

At the location of the ANDRA (French National Radioactive Waste Management Agency) underground research laboratory (Fig. 1), carbonates of the middle and late Oxfordian in the eastern Paris Basin contain permeable and porous intervals with porosities reaching more than $20 \%$. These horizons are located mainly in lagoonal facies with a micritic matrix (Ferry et al. 2007). This contrasts with the few grainstone facies, which seldom contain porosities higher than $10 \%$. However, the porous horizons do not show lateral continuity on a regional scale. These features, the availability of subsurface core samples and lateral outcrop equivalents, and the well-known diagenetic history of the basin (Carpentier et al. 2014; Brigaud et al. 2009; Vincent et al. 2007) make the Oxfordian limestones of the eastern Paris Basin an excellent target to test the different hypotheses on the origin of micropores in micrites.

The aim of the present study is to understand the sedimentary and diagenetic mechanisms that controlled the formation and the distribution of these porous facies. The main objective is to propose a diagenetic model explaining the preservation of the original porosity and/or the development of secondary porosity in some of the studied micritic limestones.

\section{GEOGRAPHICAL AND GEOLOGICAL FRAMEWORK}

The eastern margin of the intracratonic Paris Basin presents a homoclinal geometry with an inclination of about 2 degrees westward. Outcrops of Late Jurassic deposits are bounded by the Ardennes Massif to the north (Fig. 1). Several major faults cut across the eastern margin of the basin. The Vittel, Metz, and Saint-Martin-de-Bossenay faults are inherited from the Hercynian orogeny (Guillocheau et al. 2000). Most of these Hercynian faults were active during Mesozoic times (De Graciansky and Jacquin 2003; André et al. 2004). Faults of the Gondrecourt and Joinville grabens originated during the Eocene to Oligocene (André et al. 2010).

During the middle Oxfordian, a shallow carbonate platform developed in the eastern Paris Basin (Ziegler 1990; Thierry 2000; Ferry et al. 2007; Carpentier et al. 2010) located between 30 and $35^{\circ} \mathrm{N}$ (Kiessling et al. 1999). Southward, the shallow, clay-free carbonate facies graded laterally into argillaceous carbonates of the basinal environment near the Marne Valley (Fig. 2). These carbonates were deposited during a long-term progradation phase. During the late Oxfordian, climatic cooling (Lécuyer et al. 2003; Brigaud et al. 2008) led to a decrease in carbonate production, and shallow marly deposits alternated with carbonate deposits (Carpentier et al. 2006). The platform margin was still located in the Marne Valley area. Near the
Oxfordian and Kimmeridgian boundary, climatic warming (Lécuyer et al. 2003; Brigaud et al. 2008) allowed the growth of a new carbonate platform, expanding from Burgundy to the Ardennes (Lefort et al. 2011).

Several surfaces of subaerial exposure occur in Oxfordian limestones (Fig. 3). However, except in the Calcaires de Dainville Member, middle Oxfordian surfaces of subaerial exposure are devoid of signs of prolonged exposure such as karsts or caliches. In addition, features of meteoric dissolution below these surfaces are rare. In the Calcaires de Dainville Member, exposure surfaces are closely stacked. This formation was deposited during a period of low accommodation, and the occurrence of rootlets below surfaces of subaerial exposure suggests that exposure was more prolonged than in the lower part of the middle Oxfordian (Carpentier et al. 2010). In the late Oxfordian, surfaces also show indications of prolonged subaerial exposure such as karstification and vadose cements (Oolithe de Saucourt Member).

\section{SAMPLING METHODS AND ANALYTICAL TECHNIQUES}

Samples were collected in cores of wells EST204 and EST205 and in outcrops in the Pagny-sur-Meuse and Maxey-sur-Vaise quarries (Fig. 1). The Oxfordian limestones were studied using the following techniques:

- Characterization of microfacies and petrography of cements by optical microscopy and cathodoluminescence on 140 thin sections. One half of each thin section was stained with the Dickson solution (Dickson 1965) to characterize the mineralogy and chemistry of cements (dolomite vs. calcite, iron content) and to establish the chronology of cementation or dissolution phases. A CITL cold-cathode instrument CL8200 Mk4 (working conditions $15 \mathrm{kV}$ and $500 \mu \mathrm{A}$ ) was used to visualize the cathodoluminescence on the unstained half of the thin sections (or prior to staining).

- Characterization of morphologies of micrite crystals on freshly broken surfaces using secondary-electron SEM at the Department of Geosciences of Fribourg (Switzerland).

- Characterization of the pore space with petrophysical measurements, confocal microscopy, and SEM imaging. Petrophysical measurements (nitrogen adsorption and mercury intrusion porosimetry) were performed at the Louis Pasteur University in Strasbourg using Micromeritics accupyc II 1340 and AutoPore IV 9500 V1.09. Threshold values were determined by mercury injection test (MICP); therefore, given sizes are not the pore sizes but threshold values controlling the pore access. The distribution of microporosity was studied on polished samples impregnated with fluorescent resin and observed under UV light with confocal laser scanning microscopy with a horizontal resolution of about $0.1 \mu \mathrm{m}$. By collecting images in selected wavelengths of the light spectrum, this method allows separation of fluorescence due to the fluorescent resin (emission spectral range $400-600 \mathrm{~nm}$ ) in pores from the natural fluorescence produced by carbonates (see Sterpenich et al. 2009 for more details about the method). A filter was applied subsequently to images to assign colors to intensities of fluorescence, which can be directly interpreted as a porosity indicator. The size, the connectivity, and the morphology of micropores were mapped in 2D using SEM images in backscattered-electron mode (on a HITACHI S-4800 SEM) obtained with polished and goldcoated samples. Pore contours and crystal contacts were drawn after pore geometry extraction by binarizing images using ImageJ software.

- Characterization of stable-isotope composition of micrites and cements using an auto-sampler MultiPrep ${ }^{\mathrm{TM}}$ system coupled to a dual-inlet GV Isoprime ${ }^{\mathrm{TM}}$ isotope-ratio mass spectrometer (IRMS). For each sample, an aliquot of 100-200 $\mu \mathrm{g}$ of calcium carbonate reacted with anhydrous oversaturated phosphoric acid at 


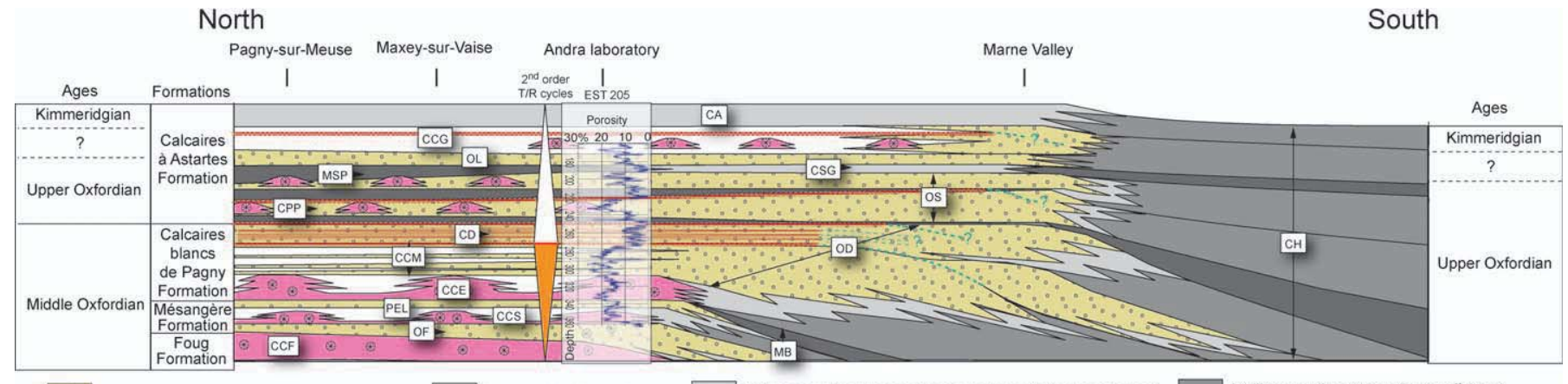

$\because$ Oolitic or oncolitic grainstones to packstones $\square$ Lagoonal chalky mudstones $\square$ Argillaceous limestones with storm deposits (upper offshore) $\square$ Argillaceous limestones (lower offshore) Lagoonal or basinal marls $\odot$ Coral buildups _ -...?.... Major surface of subaerial exposure and its possible correlative surface

Members : $\mathrm{CCF}=$ Calcaires a coraux de Foug; $\mathrm{OF}=$ Oncolithe de Foug; $\mathrm{CCS}=$ Calcaires coralliens de Sorcy; PEL = Pierre d'Euville Lérouville; $\mathrm{CCE}=$ Calcaires coralliens $d$ 'Euville; $\mathrm{CCM}=\mathrm{Calcaires}$ crayeux de maxey; $\mathrm{OD}=$ Oolithe de Doulaincourt $\mathrm{CD}=$ Calcaires de Dainville; $\mathrm{CPP}=$ Calcaires à polypiers de Pagny; OS = Oolithe de Saucourt; $\mathrm{MSP}=$ Marnes à serpules de Pagny; $C S G=C a l c a i r e s$ à serpules de Gudmont; $\mathrm{OL}=$ Oolithe de Lamothe; $\mathrm{CCG}=$ Calcaires crayeux de Gudmont; $\mathrm{CA}=$ Calcaires à astartes; $\mathrm{CH}=$ Calcaires hydrauliques; $\mathrm{MB}=$ Marnes de Bouix

FIG. 2.-Oxfordian-lithostratigraphy with vertical variations of porosity in the area of the Andra laboratory, geometries and lateral evolutions of facies along a north-to-south transect from the Pagny-sur-Meuse area toward the Marne Valley.

$90^{\circ} \mathrm{C}$ during 20 minutes. Carbon and oxygen isotope compositions are quoted in the delta notation in per mil relative to Vienna Pee Dee Belemnite (V-PDB). All sample measurements were triplicated and adjusted to the international reference NIST NBS19 with a reproducibility of $\pm 0.1 \%$ for $\delta^{18} \mathrm{O}$ values and $\pm 0.05 \%$ for $\delta^{13} \mathrm{C}$ values $(1 \sigma)$.

\section{RESULTS}

\section{Stratigraphic and Regional Distribution of Porous Facies}

In the core EST204, drilled on the site of the Andra laboratory, several intervals characterized by porosities up to $20 \%$ have been observed on quantitative DiagEval ${ }^{\circledR} \operatorname{logs}$ (Fig. 3), which are based on a deterministic calculation of total porosity using a well-log dataset (neutron, density, sonic, total or spectral gamma-ray). In this study, facies with porosities greater than $20 \%$ are called high-porosity facies (HPFs), while facies with low porosity values (less than 10\%) are considered to be low-porosity facies (LPFs). According to the correlations based on the sequence-stratigraphic interpretation of each core and each outcrop section (Ferry et al. 2007; Carpentier et al. 2010), the lateral equivalents of the HPFs of the Andra site have been located in the outcrop sections.

Various facies occur in HPF intervals (Fig. 3), including chalky inter-reefal mudstone (Calcaires coralliens d'Euville Member,), oncolitic wackestone-packstone (Pierre d'Euville-Lérouville Member and Calcaires coralliens d'Euville Member), oolitic and oncolitic packstone-grainstone with bioclasts (Calcaires crayeux de Maxey Member and Oolithe de Saucourt Formation), lagoonal chalky mudstonewackestone with scattered oncoids and bivalve shells (Calcaires crayeux de Maxey Member and Oolithe de Saucourt Formation), chalky oolitic wackestone-packstone (Calcaires crayeux de Maxey and Calcaires crayeux de Gudmont members) and pisolitic floatstone (Oolithe de Saucourt Formation and Calcaires crayeux de Gudmont Member).

HPFs exist in the five drillholes (EST104, EST201, EST203, EST204, and EST205) cored on the Andra site. They are located at similar stratigraphic positions (Fig. 4). The longest distance between two wells is about 300 meters. Consequently, the distribution of the HPFs is controlled by stratigraphy at the scale of several hundred meters. In corallian facies, porous intervals are more or less continuous both vertically and laterally because of the patchy geometry of faintly porous build-ups separated by a highly porous inter-reefal micritic matrix (Fig. 5). HPFs disappear southward when shallow platform environments grade laterally to marls and argillaceous mudstones of the Calcaires hydrauliques Formation deposited in a slope environment (Fig. 2). In contrast, some HPFs are absent or merged in several drillholes, such as EST312 and EST412, located $10 \mathrm{~km}$ north of the Andra laboratory (Fig. 1B). Consequently, lateral variations of porosity exist at the scale of several kilometers.

\section{Porosity Mapping and Petrophysical Properties}

Confocal Imaging.-Confocal imaging shows that, in grainstone facies, the porosity is mainly intragranular. Intergranular pores are entirely filled with blocky calcite, and the primary porosity is totally occluded (Fig. 6A). Grains are mainly micritic and their primary structures are commonly obliterated. However, remnants of discrete internal structures such as concentric laminations in ooids are sometimes revealed by confocal microscopy (Fig. 6A). Micritized grains have an important microporosity (Fig. 6A, B), and in grainstone facies the connectivity between microporous grains is locally enabled by porous micritic encrustations (Fig. 6B). In a few samples, a residual intergranular porosity has been preserved.

Some allochems contain only a peripheral porous fringe. They correspond to echinoid spines (Fig. 6C) as well as micritic gravels presenting irregular concentric laminations around a bioclastic nucleus (Fig. 6D) which can be pink in color on macroscopic samples (Fig. 6I). The micrite coating of these grains consists of a dense microstructure (leiolite texture sensu Braga et al. 1995). Consequently, they are interpreted as oncoids. The amounts of leiolitic oncoids and echinoid clasts are more important in LPFs than in HPFs (Fig. 6D).

In the mudstones, wackestones, and a few packstones of HPFs, the microporosity is significant (up to $20 \%$ based on the Diageval ${ }^{\circledR} \operatorname{logs}$, Fig. 3) and diffuse in the matrix (Fig. 6F). The majority of grains are micritized and porous. Only echinoid clasts are devoid of porosity

FIG. 1.-Geographical - and geological map of the studied area. A) Location of Late Jurassic outcrops and main tectonic structures of the eastern Paris Basin. B) Location of Andra wells and studied quarries. 


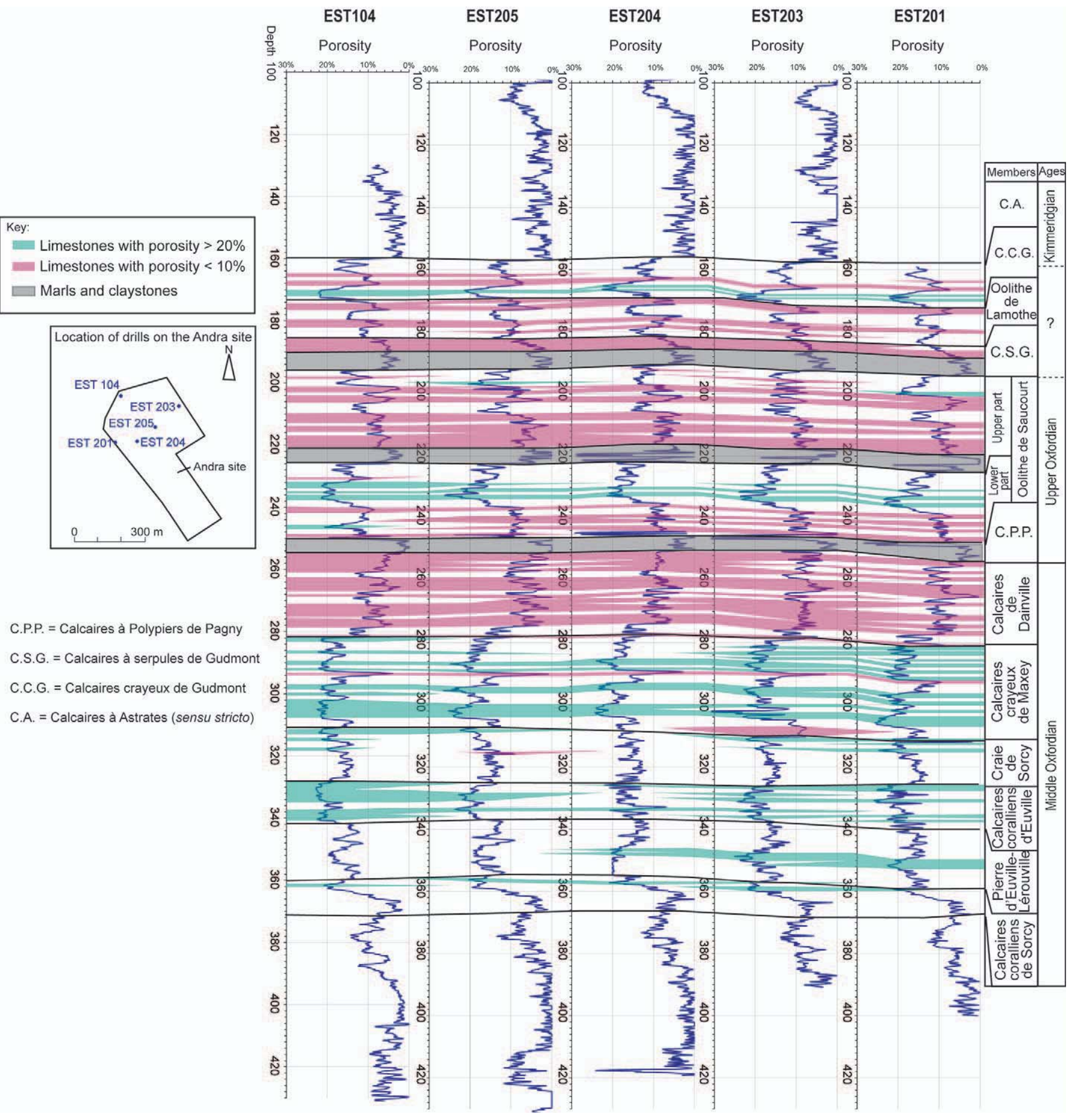

FIG. 4.- Stratigraphic - control on the location of HPFs and LPFs between wells of the Andra site.

\section{SEM OBSERVATIONS}

HPFs

In the carbonate matrix of HPFs, the microporosity is significant (Fig. 7). In 2D, the connectivity of micropores is good, and the pore diameter can reach $5 \mu \mathrm{m}$ (Fig. 7). In the vicinity of telogenetic tension gashes, crystal sizes range from 0.5 to $2 \mu \mathrm{m}$, with some scarce crystals reaching $3 \mu \mathrm{m}$ (Fig. 8A). Generally, the free edges of the crystals show a rounded morphology while the grain-to-grain contacts are straight (Figs. 7, 8A). According to the classification of Deville de Periere et al. (2011), these micrite crystals are rounded, anhedral to subhedral with punctic to partially coalescent contacts. In contrast, several millimeters from telogenetic tension gashes, larger ( 3 to $4 \mu \mathrm{m})$ euhedral crystals are associated with smaller rounded ones (Fig. 8B). Large euhedral crystals can entrap smaller ones (Fig. 8C). Crystal shapes vary from euhedral to subhedral and slightly rounded to rounded (Fig. 8B). 


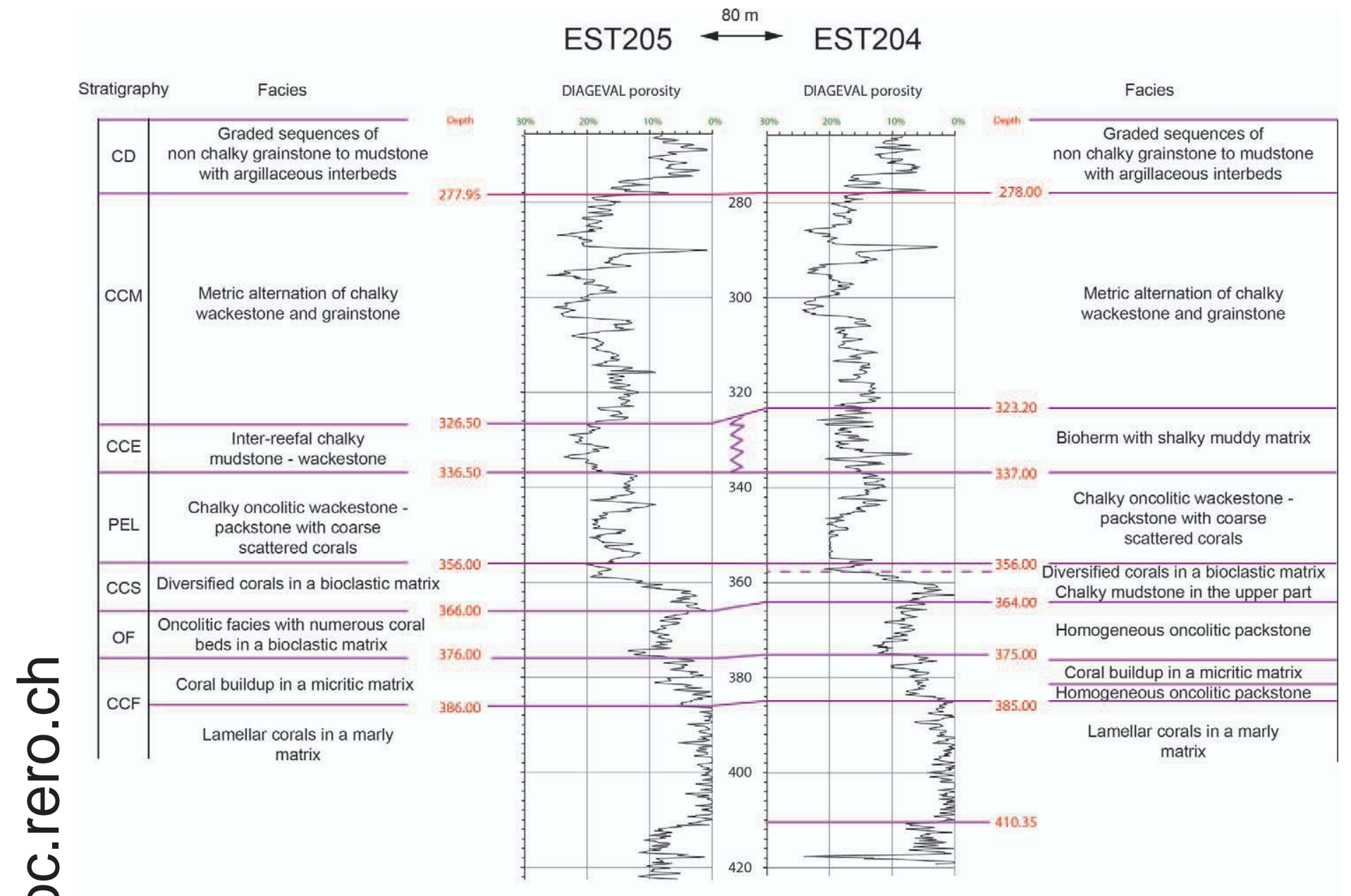

CCF = Calcaires à coraux de Foug; OF = Oncolithe de Foug; CCS = Calcaires coralliens de Sorcy; PEL = Pierre d'Euville-Lérouville; CCE = Calcaires coralliens d'Euville; $C C M=$ Calcaires crayeux de Maxey; $\mathrm{CD}=$ Calcaires de Dainville

FIG. 5.-Lateral-variation of porosity in corallian facies. Note the lateral variations of porosity in the Calcaires coralliens d'Euville Member due to the patchy geometry of coral build-ups.

Ooids are entirely micritized. The cortices contain abundant micropores and consist of rounded micrite crystals (Fig. 8E). Larger euhedral rhombs have also been observed in ooid cortices. The primary concentric structure of the cortex around a nucleus is largely erased by micritization (Fig. 8D). In stromatolitic facies of the Calcaires crayeux de Maxey Member, microbial filaments are common and locally occur between micrite crystals (Fig. 8F).

\section{LPFs}

In LPFs, crystals are coalescent (Fig. 9A). Where free faces can be observed, they show euhedral crystalline shapes (Fig. 9B). Contacts between crystals are straight or sinuous (Fig. 7). Locally, crenulated contacts are present (Fig. 9A). Visually, in 2D, the microporosity is low and poorly connected (Fig. 7). Euhedral crystals correspond to microspar with sizes ranging between 4 and $8 \mu \mathrm{m}$ (Fig. 9C). Small rounded micrite crystals with sizes ranging from 0.5 to $2 \mu \mathrm{m}$ are rare and sporadically appear entrapped within large euhedral crystals (Fig. 9C). In samples where rounded micrites are very rare and small (less than $0.5 \mu \mathrm{m}$ in size), coalescent micrite also contains small empty vacuoles of similar size (Fig. 9A, D). The faintly porous cortices of leolitic oncoids consist of a dense coalescent micrite. The external porous fringes of grains such as echinoid clasts or leolitic oncoids present a microporous aspect similar to the one observed in HPFs with crystal sizes of 1 to $2 \mu \mathrm{m}$ (Fig. 9E). In the micritized fringe, crystals are rounded with punctic to linear or sinuous contacts. Uncommonly, ooids are not totally micritized and the primary structure of the cortex is preserved. This structure consists of a radial arrangement of anhedral micrite crystals with a low microporosity (Fig. 9F).

\section{Petrophysical Properties}

Measured porosities and permeabilities are given in Table 1. Significant correlations are observed between the petrophysical properties measured by nitrogen adsorption and mercury intrusion (porosity and permeability), the intensity of micritization, the rock texture, and pressure-solution features (occurrence vs absence of pressure-solution features) (Fig. 10A). Samples were selected according to the total or partial micritization of 

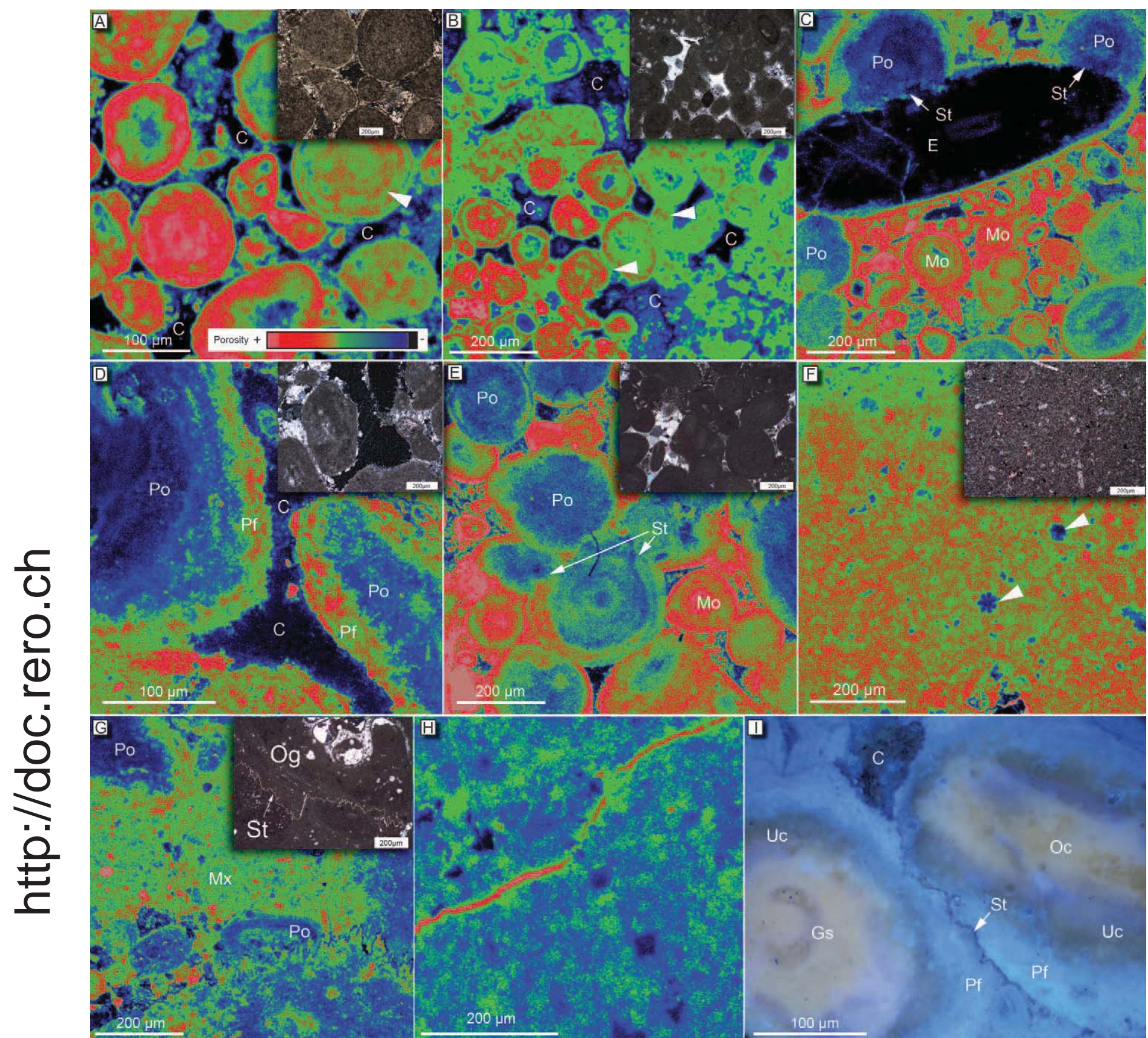

FIG. 6.-Mapping —of porosity using confocal imaging. The mapping is deduced from the intensity of fluorescence due to the quantity of fluorescent resin in filling the pores. The color scale is valid for all images. Impregnations for confocal imaging were performed on polished slabs and images in plane-polarized light were acquired on thin sections from the same samples. Therefore, locations of confocal views and views in plane-polarized light are quite different but represent similar facies. A) Grainstone with microporous ooids and intergranular porosity totally filled with blocky calcite (C). Note the remnants of the initial concentric structure of ooid cortex (arrow) (sample 25220, lower part of the Oolithe de Saucourt Member, EST 205 drill core, porosity of 22.7\%). B) Porous ooids linked by porous micritic encrustations (arrows). Intergranular porosity is totally filled by tight blocky calcites (C) (sample PPA1087, upper part of the Oolithe de Saucourt Member, EST 204 drill core, porosity of $12.4 \%$ ). C) Large nonporous echinoid spine (E) in a packstone-grainstone. Tight leiolitic oncoids (Po) and porous micritized ooids (Mo) constitute the rest of allochems. Note the presence of microstylolites (St) between grains (sample 25226, equivalent of the Craie de Sorcy Member, EST 205 drill core, porosity of $9.2 \%$ ). D) Porous fringe (Pf) on the periphery of tight oncoids (Po). Blocky calcite crystals (C) fill the intergranular porosity (sample 25215, Calcaires de Dainville Member, porosity of 4.7\%). E) Grainstone typical of LPFs. The facies is rich in large leiolitic oncoids ( $\mathrm{Po}$ ) mixed with smaller porous ooids (Mo). Note the presence of microstylolites (St) between grains (sample 25226, equivalent of the Craie de Sorcy Member, EST 205 drill core, porosity of 12\%). F) Micritic matrix showing a diffuse porosity. Only some scarce echinoid clasts are tight (arrows) (sample 25232, Calcaires coralliens d'Euville Member, EST 205 drill core, porosity of 19.4\%). G) Wackestone with a reduced matrix porosity (Mx) compared to Part F. Allochems are composed mainly of leiolitic oncoids (Po), and the facies is affected by stratiform stylolites (St). Og, oncolitic cortex around a nucleus formed by a gastropod (sample 25215, Calcaires de Dainville Member, EST 205 drill core, porosity of 4.7\%). H) Thin fringe of increased porosity on margins of a telogenetic tension gash (sample 25232, Calcaires coralliens d'Euville Member, EST 205 drill core, porosity of 19.4\%). I) Peripheral porous fringes (Pf) of leiolitic oncoids filled by fluorescent resin and impacted by micro-stylolites (St), indicating that chemical compaction was subsequent to the microporosity. A part of the 
grains. In order to avoid problems in the definition of intermediate stages of micritization, only samples with entirely micritized grains or grains with a peripheral fringe were selected. This selection allowed use of a binary definition of the intensity of micritization. This classification is qualitative and based entirely on observations of confocal imaging. The most porous and permeable samples are the most micritized ones, and they contain a micritic matrix devoid of stylolites. Grains impacted by peripheral micritization in samples with both low porosity and permeability consist mainly of echinoid clasts and leolitic oncoids. In addition, facies with a micritic matrix having the lowest porosities are often affected by stylolites.

For the majority of samples, the mean pore-throat diameter is equal to the median (Fig. 10B), indicating a homogeneous distribution of porethroat diameter. The distribution of the pore-throat diameters is unimodal with values between 0.04 and $3 \mu \mathrm{m}$ (Fig. 11A). Two samples (Pag 40 and Max 32) have a mean value of pore-throat diameter higher than the median. This shift indicates the presence of large pores. The range of pore-throat sizes is between $0.02 \mu \mathrm{m}$ and $400 \mu \mathrm{m}$. The distribution of pore-throat diameters in both samples is trimodal, with peaks at about $0.4 \mu \mathrm{m}, 3.5 \mu \mathrm{m}$, and $150 \mu \mathrm{m}$ (Fig. 11B).

\section{Paragenesis}

A paragenesis sequence has recently been proposed for the Middle and Late Jurassic limestones of the eastern Paris Basin by Carpentier et al. (2014) (Fig. 12). This work was based on observations of diagenetic phases in macropores and fractures. However, until now no study has been performed on the impact of diagenesis on microporosity, Therefore, in the present study, this diagenetic framework is compared with observations at the micropore scale in order to correlate the evolution of micrite morphologies with the successive diagenetic events identified at the macropore scale. The sequence is summarized below.

\section{Eogenesis}

Signs of biological micritization are common in all facies. This phenomenon totally or partly affected grains such as ooids while it impacted only the periphery of echinoid clasts and oncoids (Fig. 13). Dissolution features such as early moldic porosity, vadose silts or dissolution vugs, and early cements below surfaces of subaerial exposure are rare. In contrast, aragonite was rapidly replaced by low-magnesium calcite in skeletal structures of foraminifera (Reid and Macintyre 1998), corals (Rabier et al. 2008), or bivalves (Maliva et al. 2000). Dissolution or replacement occurred when pore water was highly or slightly undersaturated with respect to aragonite and depended on the intensity of fluid renewal in a closed or open system (Melim et al. 2002) during late eogenesis or early burial. In the Oxfordian of the eastern Paris Basin, this process generated replacement of aragonite by neomorphic calcite or the development of dissolution vugs in skeletal grains with an original aragonitic mineralogy.

\section{Mesogenesis and Telogenesis}

In grainstones, most of the cementation took place during burial until the Late Cretaceous (dolomite Doll and blocky calcite Cal2, Fig. 12). Comparison of REE composition of cements, host rocks, and Oxfordian seawater show that this cementation phase was favored by chemical compaction (Carpentier et al. 2014). Fluids at the origin of the blocky calcites correspond to a mixing between formation waters and meteoric waters infiltrated by lateral recharge of deep aquifers during the early Cimmerian (LCU) and early Aptian (LAU) subaerial exposure phases of the basin margins (Guillocheau et al. 2000). In contrast, due to their entrapping in a micrite matrix that prevented significant lateral fluid percolation, coral dissolution vugs occurring in muddy porous facies during eogenesis or early burial were not or only very faintly affected by this cementation phase. Cementation in theses vugs occurred during Cenozoic telogenesis when Pyrenean, Oligocene, and Alpine fracturing generated preferential vertical meteoric-fluid pathways favoring the deep penetration of meteoric waters and precipitation of late cements (calcites Cal3 and Cal4 and dolomite Dol2).

\section{Stable Isotopes}

A stable carbon and oxygen isotope study has been performed on micrite crystals (Fig. 14). Sampling was performed on the coalescent micrite of the matrix as well as on grains. In LPFs $\delta^{13} \mathrm{C}$ values range from +2.8 to $+3.2 \%$ and $\delta^{18} \mathrm{O}$ values from -5.2 to $-3.7 \%$. HPFs are characterized by a larger range of isotopic values than for LPFs with $\delta^{18} \mathrm{O}$ and $\delta^{13} \mathrm{C}$ values that range from- 6.1 to- $3.0 \%$ and from +2 to $+3.7 \%$, respectively. A covariant trend with a linear $\delta^{18} \mathrm{O}$ and $\delta^{13} \mathrm{C}$ fall can be observed in micrites of HPFs.

Using the oxygen isotope fractionation equation determined by O'Neil et al. (1969) for inorganic calcite, theoretical $\delta^{18} \mathrm{O}$ values of cements precipitated from marine or mixed marine-meteoric waters were calculated for different temperatures.

$$
\delta^{18} \mathrm{O} \text { calcite }(\mathrm{SMOW})-\delta^{18} \mathrm{O} \text { water }(\mathrm{SMOW})=2.78 .10^{6} / \mathrm{T}^{2}-3.39 \text {. }
$$

$$
(\mathrm{SMOW}=\text { Standard Mean Ocean Water, } \mathrm{T}=\text { temperature in } \mathrm{K})
$$

$\delta^{18} \mathrm{O}_{\text {(SMOW) }}$ of surface seawaters during the Jurassic in the Paris Basin is estimated around 0\% (Lécuyer et al. 2003; Pucéat et al. 2003; Brigaud et al. 2008, 2009) and seawater temperature was between $20^{\circ} \mathrm{C}(293 \mathrm{~K})$ and $25^{\circ} \mathrm{C}(298 \mathrm{~K})$ (Lecuyer et al. 2003; Brigaud et al. 2008). Clauer et al. (1995), Elie et al. (1999), and Blaise et al. (2014) showed that maximum burial temperatures of Oxfordian formations in the eastern Paris Basin did not exceed $50^{\circ} \mathrm{C}(323 \mathrm{~K})$. The Paris Basin was located in an intertropical position throughout the Jurassic. Considering present-day $\delta^{18} \mathrm{O}$ values of rainfall at low latitudes and low elevations (Lachniet and Patterson 2009) and estimated values (about $-5 \%$ SMOW) for the end of the Mesozoic (Suarez et al. 2009), we assume that $\delta^{18} \mathrm{O}$ values of tropical Oxfordian meteoric waters were about $-4 \pm 1$ ( $\%$ SMOW). The results of the various calculations are given in Table 2 .

\section{DISCUSSION}

\section{Impact of Initial Texture, Mineralogy, and Biological Micritization}

In HPFs, petrophysical data (Fig. 11A) show that the range of porethroat sizes is coherent with a microporosity located in micrites (Moshier 1989a) as observed with confocal and SEM imaging. For HPFs, samples contain a micritic matrix and micritized grains (Fig. 10A).

\section{Matrix}

As revealed by petrophysical measurements, the occurrence of micrite matrix increased the rock permeability (Fig. 10A). Needles, which

FIG. 7.-Backscattered-SEM - photomicrographs of geometries and distribution of pores in micrites. In HPFs, the porosity is connected and pore diameters can reach $5 \mu \mathrm{m}$. Micrite crystal surfaces are smoothed and sizes range from $0.5 \mu \mathrm{m}$ to $3 \mu \mathrm{m}$. Note the linear contacts between the crystals (sample Max26, porosity of $20.7 \%$ ). In LPFs the porosity is low and pores are poorly connected or unconnected. The micrite consists of subhedral to euhedral crystals with linear contacts (sample PPA1093, porosity of $7.8 \%$ ). 
HPF

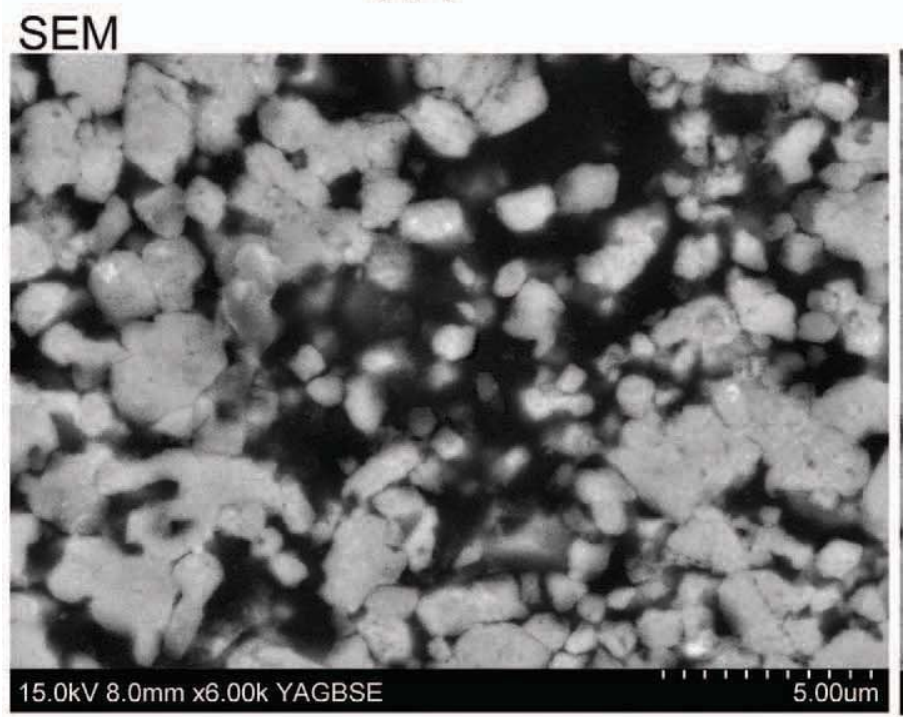

LPF

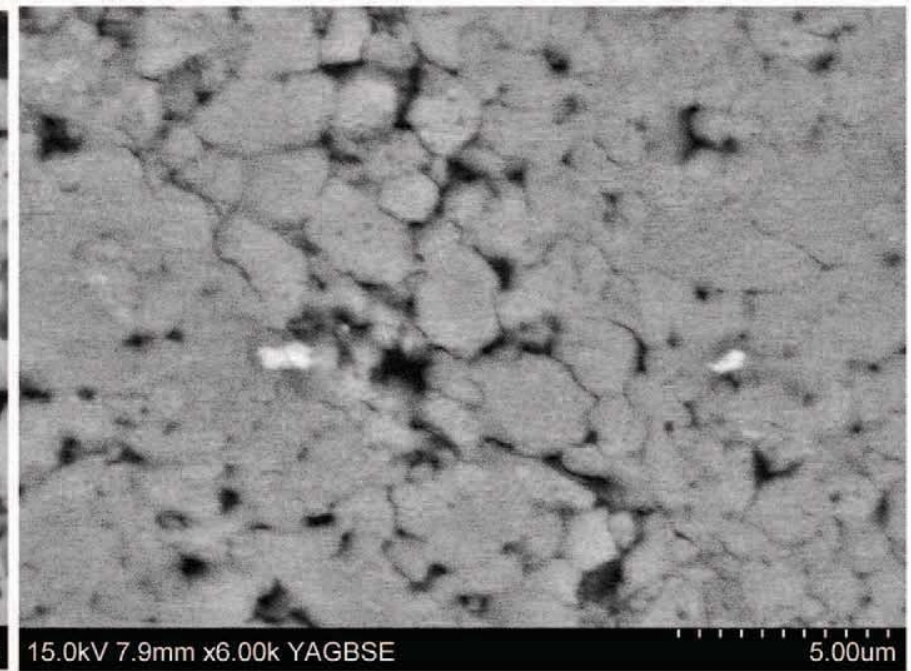

Binarized image

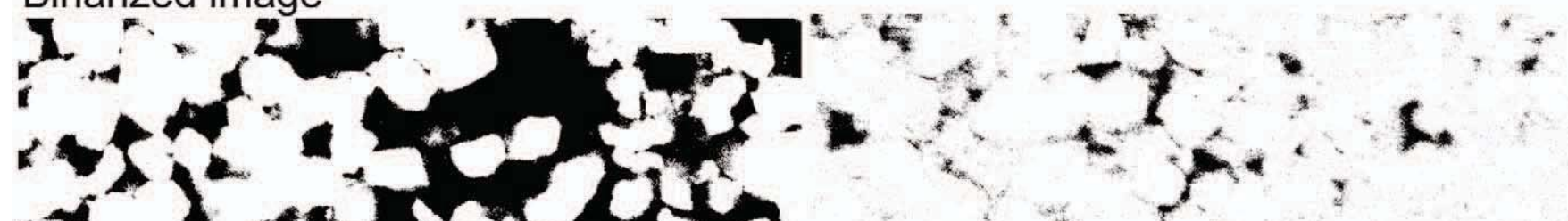

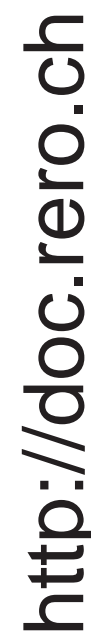

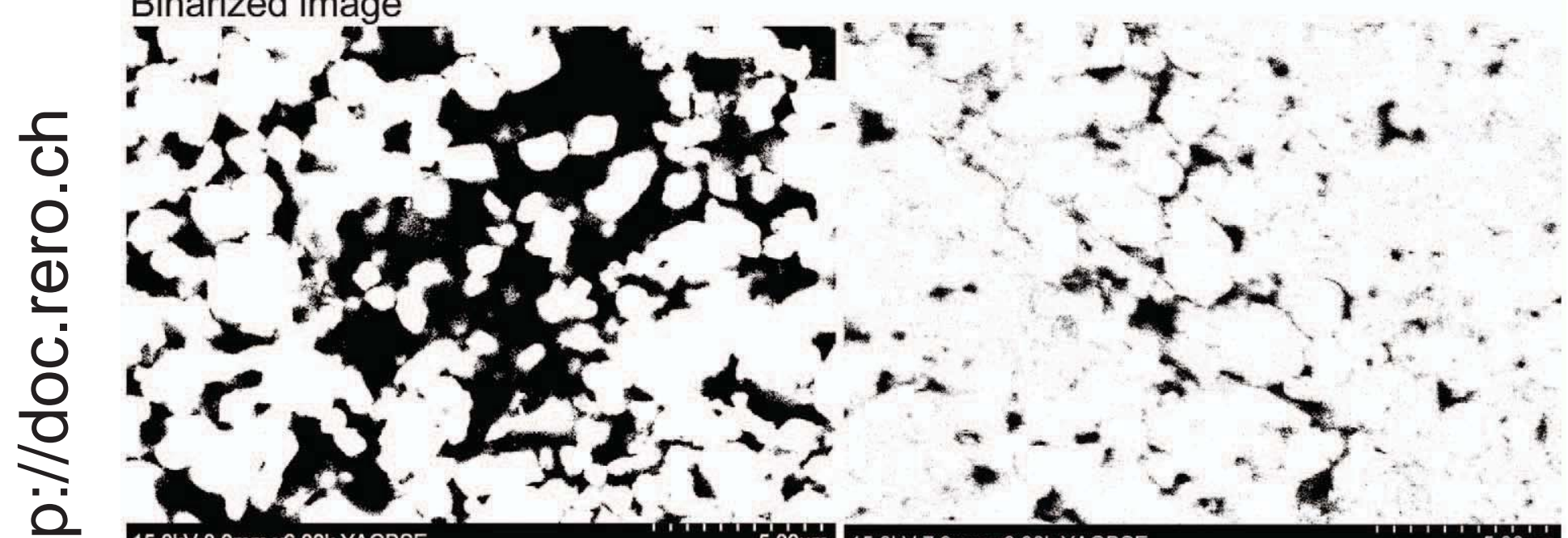
$15.0 \mathrm{kV} 8.0 \mathrm{~mm} \times 6.00 \mathrm{k}$ YAGBSE

$5.00 \mathrm{um} 15.0 \mathrm{kV} 7.9 \mathrm{~mm} \times 6.00 \mathrm{k}$ YAGBSE

$5.00 u m$

Mapping of nanopores

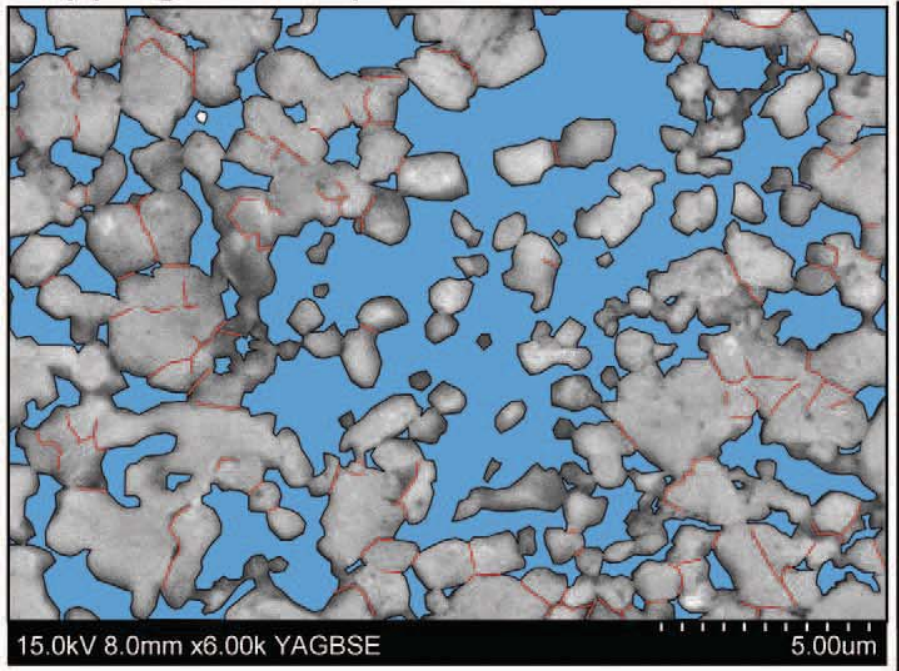

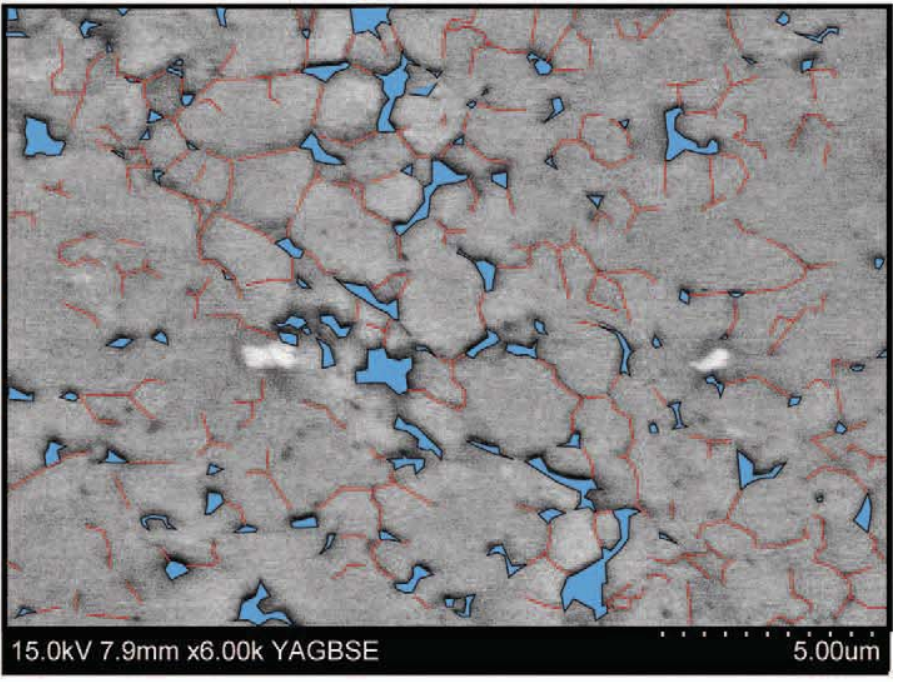

5.ooum

Porosity

Crystal contacts 
generally consist of aragonite, are lacking in the Oxfordian mudstones due to the early mineralogical stabilization of lime muds. Original lime muds, whose porosity is estimated at about 65 to $80 \%$ (Moshier 1989a), are poorly sorted and consist of a mixture of aragonitic and calcitic microclasts and equant crystals (Steinen 1978). During the Oxfordian, the majority of nonskeletal grains (e.g., ooids) and lime muds were calcitic (Loreau 1982; Sandberg 1983). However, since many corals, most gastropods, the majority of green algae, and numerous bivalve shells were aragonitic and conserved this mineralogy even during calcite-sea periods (Flügel 2004; Ries 2005), it is rational to consider that some skeletal aragonitic microclasts or needles generated by physical or biological erosion were present in the muds. According to Steinen (1978), metastable aragonite is not directly replaced by low-magnesium calcite but is rapidly dissolved during early diagenesis on or just below the sediment surface (Palmer et al. 1988). However, this process is not limited to eogenesis and may continue during burial (Melim et al. 2002). This dissolution process releases bicarbonate and carbonate ions into the aqueous solution, which likely are used for the growth of calcite rhombs on pre-existing calcite nuclei (Steinen 1978, 1982). As a consequence, and since aragonitic needles constitute the smaller particles in lime muds (Folk 1965; Volery et al. 2010), this stabilization phase generates a homogenization of crystal sizes and morphologies and a poronecrosis (Moshier 1989b; Steinen 1978).

Considering this process, mainly calcitic mineralogy of initial sediments is the most favorable for preservation of microporosity in micritic matrix or in grains (Volery et al. 2009a). Indeed, as postulated by Lasemi and Sandberg (1984), in original muds consisting mainly of calcite, early aragonite dissolution, subsequent calcite overgrowth, and poronecrosis are limited. Therefore, during the Oxfordian the initial mineralogy of lime muds dominated by calcite was favorable to the preservation of micropores.

\section{Grains}

As revealed by SEM imaging (Fig. 8E), micritization induced important transformations of the porous network in grains. As attested by the results of petrophysical analysis (Fig. 10A), the extent of this micritization controlled the total porosity in grainstone facies. SEM imaging shows that micritization totally or superficially obliterated the primary structure of the grains and generated a secondary intragranular microporosity in the Oxfordian limestones of the eastern Paris Basin. The occurrence of remnants of concentric laminations in micritic grains indicates that most grains were micritized after deposition and do not correspond to originally micritic peloids or intraclasts. Porous micritized fringes, located on the periphery of leolitic oncoids, are crosscut by burial pressure-solution seams (Fig. 6I), indicating that micritization and the appearance of microporosity occurred at shallow depths before deep burial and chemical compaction. In addition, the occurrence of microborings with micrite fillings (Fig. 13B) suggests that some micritization of grains resulted from biological micritization during eogenesis rather than by concurrent infilling (sensu Reid and Macintyre 2000) during the growth of the cortices. This micritization altered the initial structure of grains on the sea floor and allowed the precipitation of small micrite crystals in microborings (Bathurst 1966).

However, echinoid clasts or spines and leolitic oncoids are tight (Fig. 6C). The initial structure of echinoids consists of a porous network within a monocrystal of magnesian calcite (Fell and Pawson 1966). This monocrystalline structure allows syntaxial calcitic overgrowths that entirely occlude microporosity. Cathodoluminescence microscopy revealed that, in the Oxfordian limestones of the eastern Paris Basin, the first stages of syntaxial cements occluding the primary intragranular microporosity of echinoid clasts are nonluminescent (Fig. 15). This observation indicates that this cement precipitated during early diagenesis within an oxidizing environment and rapidly filled the porous network of echinoids. The cortices of oncoids probably consisted of a dense leolitic micrite, which has been preserved and stabilized during diagenesis. The resistant initial or early-acquired structure of these grains was only weakly impacted by microborings, and only a porous external fringe formed.

Grainstones cemented by burial calcites correspond to LPFs (Fig. 10A). However, two samples (Pag 40 and Max 32) are characterized by the presence of large pore throats (Figs. 10B, 11B). In optical microscopy, these samples display a residual intergranular porosity and a moldic porosity (Fig. 16A) due to an early dissolution stage below an Oxfordian subaerial exposure surface. Despite a porosity higher than $18 \%$, the samples have reduced permeability (Fig. 10A). These samples are not affected by stylolites but are largely cemented by burial calcites (Cal2, bright orange in cathodoluminescence) (Fig. 16A). Grains also show an intragranular microporosity (Fig. 16B). However, the grains are not connected but are separated by blocky calcite. This feature explains the low permeability of samples Pag 40 and Max 32 .

\section{Origin of Rounded Micrites}

Confocal and SEM observations show that the distribution of microporosity in both grains and matrix is related to the morphology of the micrite crystals. Large coalescent anhedral to euhedral blocky micrites are correlated with LPFs, while HPFs are associated with small rounded crystals locally entrapped in larger euhedral rhombs. The rounded morphology of micrite crystals can be interpreted in four ways. i) Water rich in $\mathrm{Mg}^{2+}$ can poison the surfaces of calcite crystals, inhibit their growth, and generate a rounded growth shape (Loreau 1982; Lambert et al. 2006). ii) Dupraz et al. (2009) evidenced that in microbial mats "organic molecules can attach and poison specific crystal faces." iii) In contrast, a rounded morphology may be due to a simple dissolution by an aqueous reactive fluid (Lambert et al. 2006; Da Silva et al. 2009; Deville de Periere et al. 2011; Jobard et al. 2013). iv) Ostwald ripening in water undersaturated with respect to calcite can generate dissolution and rounding of small micrite particles during growth of the biggest ones (Leonide et al. 2014; Volery et al. 2010; Lambert et al. 2006). In the Oxfordian of the eastern Paris Basin, rounded micrite crystals in the matrix are not limited to stromatolitic facies. In addition, a diversity in crystal shapes can be observed, from small blunt calcite rhombs to totally rounded crystals (Fig. 8B). These observations suggest that, in the matrix, rounded morphotypes are not due to poisoning by organic molecules but are rather due to the dissolution of the free edges of pre-existing rhombs. However, in cortical micrites of ooids where the initial radial structure is preserved, a rounded growth shape due to poisoning by organic matter cannot be excluded. Moreover, rounded forms are engulfed in larger euhedral crystals. This observation is not in agreement with a primary origin of rounded micrites. Given the euhedral shape of large rhombs, the calcite growth was not perturbed by a parent fluid enriched in $\mathrm{Mg}^{2+}$ or by poisoning by organic matter. Therefore, if a rounded shape was the original growth morphology of small micrites, and since original shapes of particles are not preserved during aggradation (Steinen 1978), it should have aggraded into a euhedral shape at the same time as the growth of the larger rhombs. On the contrary, these observations suggest that small micrite crystals dissolved contemporaneously with the growth of large rhombs. The linear grain-to-grain contacts between rounded micrites and smooth rhombs indicate that a growth phase of micrites predated the dissolution phase. This growth phase is certainly related to the mineralogical stabilization process of lime muds during early diagenesis as mentioned above.

Vincent et al. (2004) observed micritic bridges between microcrystals and interpreted them as resulting from a reprecipitation process subsequent to dissolution triggered by meteoric waters. Such processes 

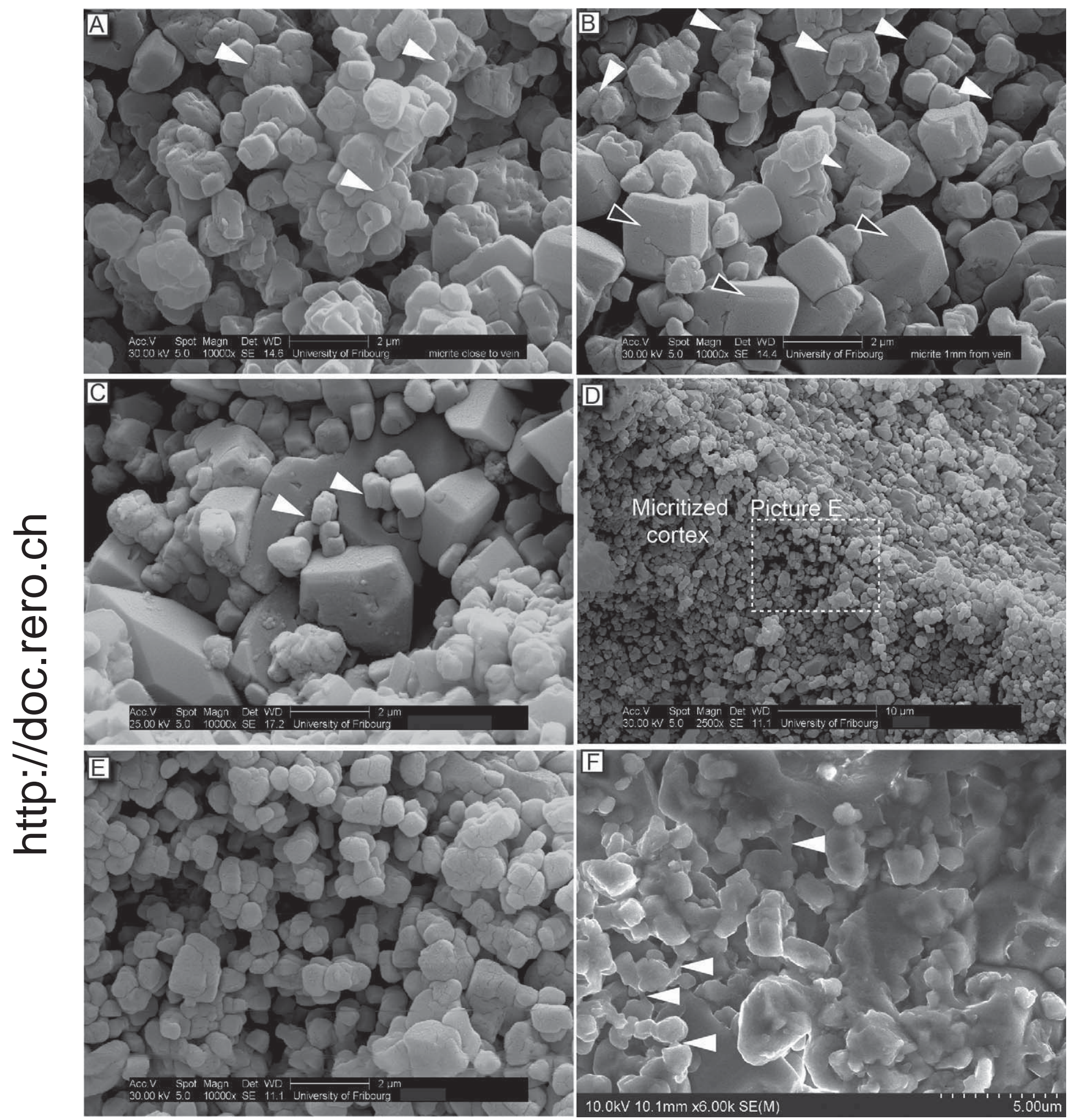

FIG. 8.-Secondary-electron SEM photomicrographs of microscopic morphologies of micrite crystals in HPFs. A) Rounded micrite crystals with sharp straight contacts (arrows) in the vicinity of a telogenetic tension gash (sample 25186, EST 205 drill core, Pierre d'Euville-Lérouville Member). B) Smoothed micrite rhombs (white arrows) and larger euhedral crystals (black arrows) in matrix $1 \mathrm{~mm}$ away from telogenetic tension gashes (sample 25186, EST 205 drill core, Pierre d'Euville-Lérouville Member). C) Small, rounded micrite crystals engulfed in large euhedral calcite rhombs (arrows) (sample 25232, EST 205 drill core, Calcaires coralliens d'Euville Member). D) Micritized cortex of ooid. The primary structure is totally erased (sample PPA 1124, EST 204 drill core, Calcaires crayeux de Maxey Member). E) Zoom on the cortex of Part D. Micrite crystals are rounded with straight contacts. Microporosity is significant. F) Micrite crystals in stromatolitic facies. They are rounded, and some microbial bridges exist between crystals (arrows) (sample Pag 65, Pagny-sur-Meuse quarry, Calcaires crayeux de Maxey Member). 
TABLE 1.-Values of permeability and porosity measured with nitrogen adsorption and mercury intrusion porosimeter.

\begin{tabular}{lcccc}
\hline \hline Sample & $\begin{array}{c}\text { Medium Pore Size } \\
\text { Diameter }(\mu \mathrm{m})\end{array}$ & $\begin{array}{c}\text { Median Pore Size } \\
\text { Diameter }(\mu \mathrm{m})\end{array}$ & $\begin{array}{c}\text { Total } \\
\text { Porosity }(\%)\end{array}$ & $\begin{array}{c}\text { Permeability } \\
(\mathrm{mD})\end{array}$ \\
\hline PAGWO & 0.1015 & 0.095 & 8.2136 & 0.002 \\
PPA1093 & 0.0877 & 0.0882 & 7.8341 & 0.006 \\
25215 & 0.0631 & 0.0503 & 4.7752 & 0.002 \\
PPA1127 & 0.2097 & 0.1893 & 13.7351 & 0.099 \\
MAX32 & 0.1643 & 0.1014 & 11.6934 & 0.055 \\
PPA1147 & 0.3205 & 0.3179 & 16.8998 & 0.162 \\
25181 & 0.347 & 0.3234 & 16.0891 & 0.537 \\
PAG13 & 0.3795 & 0.3835 & 23.988 & 0.453 \\
25232 & 0.2818 & 0.3018 & 19.4621 & 0.618 \\
PPA1139 & 0.5406 & 0.529 & 18.6893 & 1.419 \\
MAX12 & 0.443 & 0.4433 & 27.9418 & 0.567 \\
PAG65 & 0.4184 & 0.4108 & 24.4379 & 0.922 \\
PPA1129 & 0.2039 & 0.1732 & 14.6768 & 0.132 \\
MAX26 & 0.2926 & 0.2871 & 20.7054 & 1.236 \\
25220 & 0.4131 & 0.3933 & 22.7228 & 0.679 \\
PPA1104 & 0.3018 & 0.3064 & 19.455 & 0.334 \\
PAG40 & 0.3541 & 0.1111 & 16.8139 & 0.142 \\
PPA1087 & 0.2144 & 0.2158 & 12.3694 & 0.059 \\
\hline
\end{tabular}

could explain the low $\delta^{18} \mathrm{O}$ values of micrites compared to those that should have been precipitated in equilibrium with seawater. However, phenomena of dissolution and reprecipitation of micrites generally generate crystal overgrowths instead of bridges (Moshier 1989a). Therefore the bridges observed by Vincent et al. (2004) in porous limestones of the late Oxfordian rather correspond to microbial filaments (Chafetz and Buczynski 1992; Mutti 2000; Hillgärtner et al. 2001). The fact that we observed such bridges only in stromatolitic facies is consistent with the interpretation of a microbial origin

The association of rounded micrites engulfed in large rhombs was already described in numerous porous micritic formations (Lambert et al. 2006; Richard et al. 2007; Da Silva et al. 2009; Volery et al. 2010) and was interpreted as growth of large calcites at the expense of smaller ones. This process corresponds to aggrading neomorphism (Folk 1974; Steinen 1978; Moshier 1989b), also named Ostwald ripening (Ostwald 1887). This phenomenon corresponds to the dissolution of the smallest particles, furnishing ions for the growth of the larger ones of similar mineralogy. This process is caused by exchange of ions from the energetically less stable small particles to more stable large ones. In coalescent micrites, this process was enhanced since only small remnants of rounded micrites less than $0.5 \mu \mathrm{m}$ in size occur. The occurrence of these remnants preserved and encompassed by large calcite rhombs (Fig. 9C, D) in the vicinity of vacuoles of similar size suggests that the vacuoles correspond to imprints of dissolved rounded micrites. Several authors have suggested that this process is particularly efficient during early diagenesis in meteoric phreatic lenses located below surfaces of subaerial exposure (Lasemi and Sandberg 1984; Volery et al. 2009a, 2009b, 2010). However, the "hybrid Ostwald ripening" described by Volery et al. (2010) below surfaces of subaerial exposure of the Urgonian of the Jura Mountains rather corresponds to the mineralogical stabilization process of lime muds (dissolution of aragonite particles and coeval growth of calcite rhombs) and not strictly to Ostwald ripening. In contrast, Steinen (1978) and Moshier (1989b) argued that aggrading neomorphism is absent during early diagenesis but acts during burial. Such timing seems consistent with our observations, since Ostwald ripening is the last diagenetic event recorded in the studied micrites and postdates a first phase of crystal overgrowth of small rounded micrites certainly due to mineralogical stabilization. In addition, in HPFs the dominance of rounded micrite crystals in the vicinity of telogenetic tension gashes suggests that undersaturated Tertiary fluids (Carpentier et al. 2014) locally impacted the texture of the micritic sediments. However, simple dissolution by telogenetic fluids is certainly not at the origin of rounded micrites associated with large euhedral rhombs away from tension gashes. Indeed, if this had been the case, the rhombs should also have been impacted by dissolution. In contrast, fluids probably became gradually less undersaturated away from fractures and favored Ostwald ripening.

The occurrence of root traces and lignite beds above most of the subaerial exposure surfaces (Carpentier et al. 2010) in Oxfordian limestones suggests that soils developed during exposures. As a
A

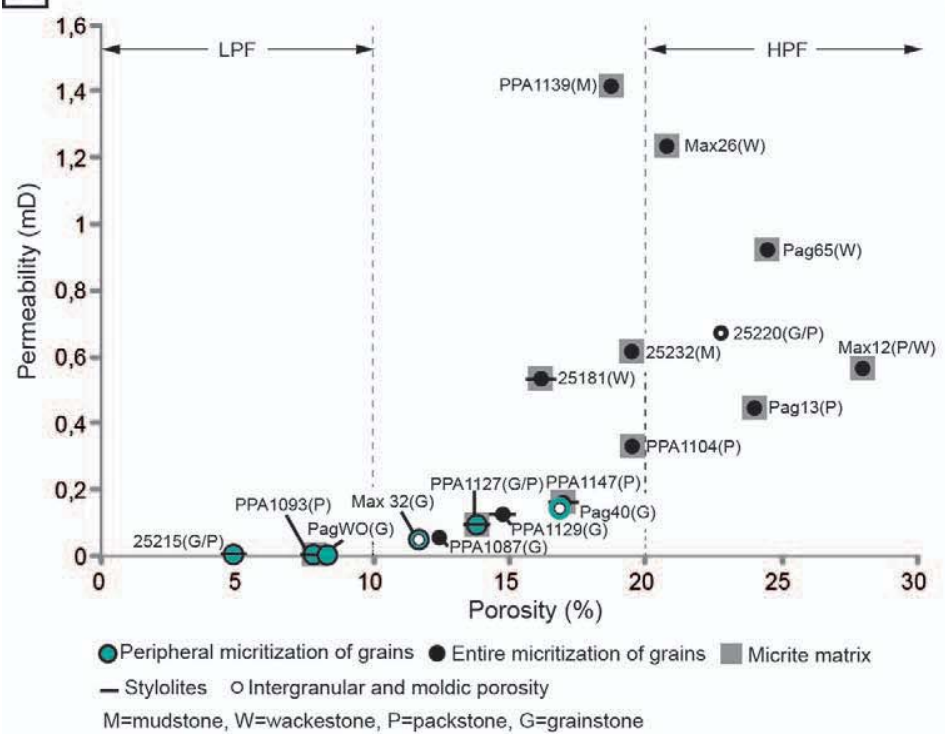

B

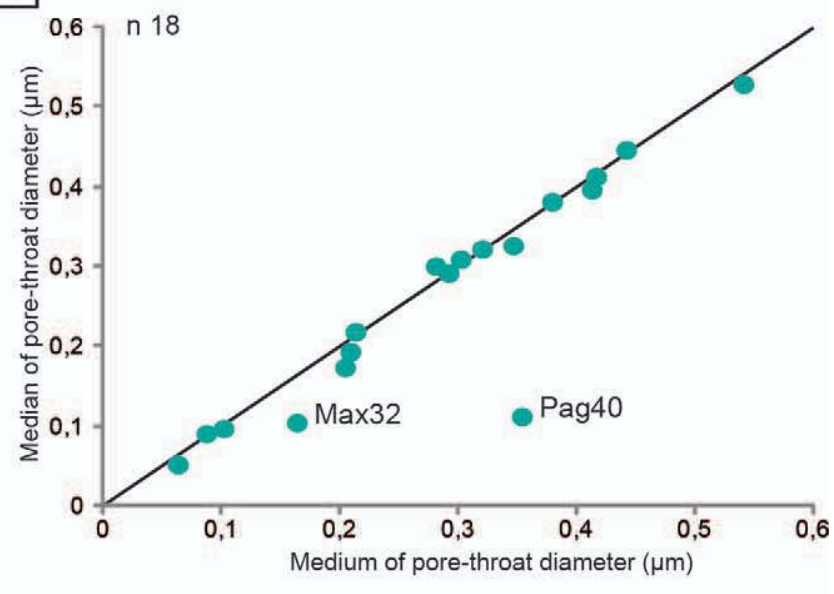

FIG. 10.-Petrophysical - properties of Oxfordian limestones of the eastern Paris Basin. A) Diagram of porosity versus permeability. The lowest porosity values correspond to grainstones and samples impacted by chemical compaction (stylolites), and the highest values correspond to entirely micritized facies with a micritic matrix devoid of chemical compaction. B) Diagram of medium versus median values of pore-throat diameter measured on plugs. Except for samples Pag 40 and Max 32 , the mean is equal to the median, indicating a homogeneous (Gaussian) distribution of pore-throat sizes. 
A

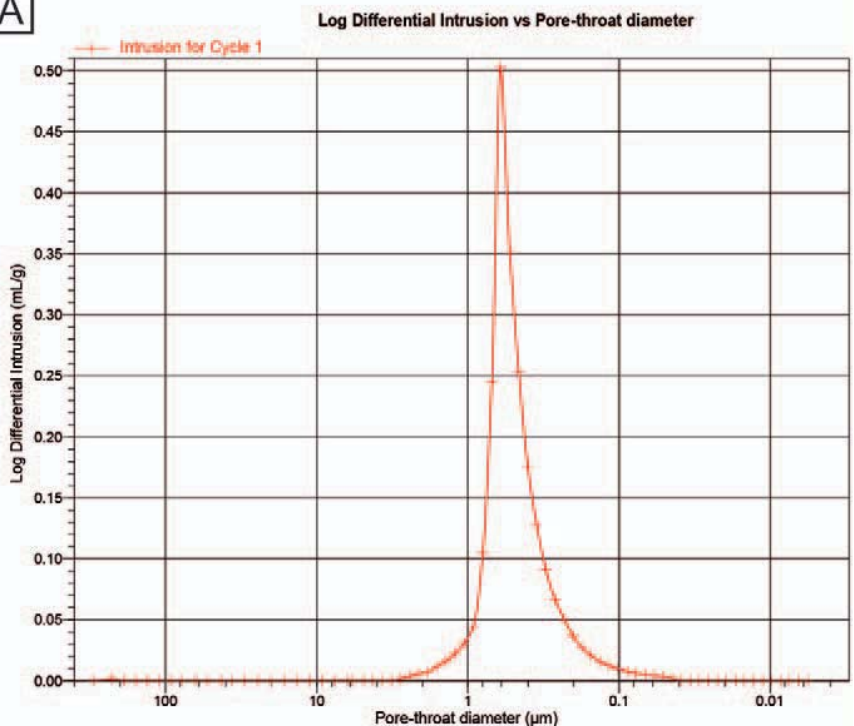

B

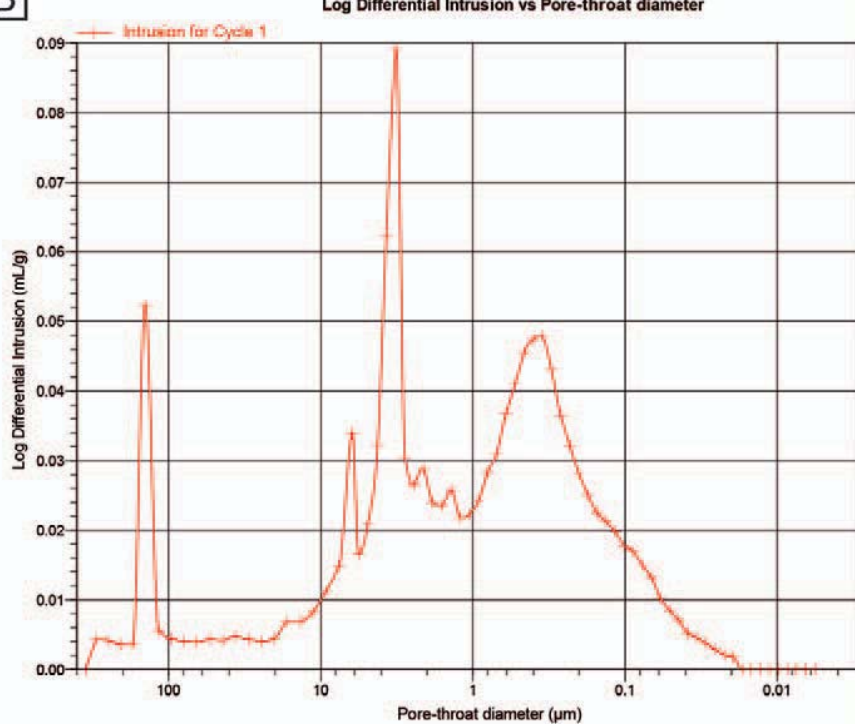

FIG. 11.-Diagrams - of log-differential intrusion versus pore-throat diameter. A) Common distribution of pore-throat size in porous micrite. The distribution of pore-throat diameters is unimodal, and the mean size is lower than $1 \mu \mathrm{m}$. B) Particular distribution of pore-throat diameters in sample Pag 40. Pore-throat diameters range from 0.02 to $400 \mu \mathrm{m}$, with peaks around $0.4 \mu \mathrm{m}$ (micrites), $3.5 \mu \mathrm{m}$, and $150 \mu \mathrm{m}$.

consequence, waters infiltrated from these surfaces were certainly enriched in ${ }^{12} \mathrm{C}$. However, $\delta^{13} \mathrm{C}$ values of micrites in HPFs are positive. If only precipitation from meteoric fluids happened during eogenesis, the $\delta^{13} \mathrm{C}$ signal would be shifted to negative values (Volery et al. 2010; Deville de Periere et al. 2011). Therefore, positive values indicate that carbon isotope compositions have been buffered by the surrounding carbonate rocks. This interpretation implies that aggradation of the studied micrites occurred at least partly during burial or telogenesis. Therefore, even if early meteoric cementation existed, the positive $\delta^{13} \mathrm{C}$ values indicate that calcite growth during burial and/or telogenesis was important enough to control the final isotopic signal. The covariant trend of $\delta^{13} \mathrm{C}$ and $\delta^{18} \mathrm{O}$ observed in micrites of HPFs is typical of precipitation in mixed meteoric groundwaters and subsurface brines in a deep aquifer (Moshier 1989a;
Choquette and Steinen 1980). However, oxygen-isotope compositions of micrites that range from $-6.1 \%$ to $-3.0 \%$ are higher than those of burial and telogenetic calcites (Fig. 14) and those calculated for high-temperature $\left(45^{\circ} \mathrm{C}\right)$ isotopic fractionation between calcite and brackish waters (Table 2). Contrarily to blocky calcites, micrite crystals aggraded from a marine precursor during diagenesis. Consequently, the oxygen isotope ratios measured in micrites reflect the mixture of the composition of the original marine crystals and that of their overgrowth, which can be either marine, brackish, or meteoric in origin. This can explain the measured shift in oxygen isotope compositions of micrites compared to values predicted for calcite precipitated from a brackish fluid at $45^{\circ} \mathrm{C}$ or calcite from seawater at $45^{\circ} \mathrm{C}$ (Table 2). Similar isotopic values have been published by Lambert et al. (2006), who analyzed Mishrif carbonates. These authors do not exclude an impact of mesogenetic meteoric fluids during the aggradation of micrites. Budd (1989) also published similar isotopic data for a micritic facies affected by aggradation due to inputs of meteoric waters during burial in the Early Cretaceous of the Arabian Gulf region.

\section{Origin of Coalescent Micrites}

The location of HPFs and LPFs seems to be mainly controlled by the initial texture of the sediment (low porosity in facies devoid of matrix vs. high porosity in facies with a carbonate matrix) (Fig. 17). However, in facies with a muddy matrix, the porosity is low (locally less than $10 \%$ ) just below surfaces of subaerial exposure compared to other parts of the section (Fig. 17). Enhancement of mineralogical stabilization and poronecrosis in meteoric diagenetic environments because of the low content in $\mathrm{Mg}^{2+}$ of meteoric waters and of their ability to flush away this cation (Folk 1974; Steinen 1978; Maliva et al. 2000) could explain such a stratigraphic relation. However, the absence of signs of prolonged exposure and the scarcity of meteoric-dissolution features below these surfaces in middle Oxfordian limestones, except in the Calcaires de Dainville Member, suggest that perennial meteoric phreatic lenses did not develop below these surfaces and that early cementation by mineralogical stabilization was not largely enhanced. In the Calcaires de Dainville Member, where exposure surfaces are closely stacked and show signs of prolonged exposures, HPFs are never encountered in intervals with a micritic matrix. In the late Oxfordian, muddy facies also show low porosity values below surfaces of subaerial exposure (Fig. 17). The more perennial exposures in the Calcaires de Dainville Member and in the late Oxfordian may have favored the appearance of successive ephemeral meteoric lenses. In the Calcaires de Dainville Member, meteoric diagenesis probably impacted the same sediment several times due to the vertical closeness of surfaces. This process may have enhanced the mineralogical stabilization of micrites and early cementation.

However, in the Oxfordian limestones of the eastern Paris Basin, some facies with a micritic matrix distant from surfaces of subaerial exposure are characterized by moderate to low porosities (e.g., upper part of the Oolithe de Lamothe Member, upper part of the Oolithe de Saucourt Formation; Fig. 17). Mineralogical stabilization is not efficient enough to generate a total closure of the porosity and the appearance of the coalescent mosaic texture observed in LPFs (Steinen 1978; Moshier 1989a). In addition, as explained above for micrites of HPFs, positive $\delta{ }^{13} \mathrm{C}$ values of micrites measured in LPFs of the eastern Paris Basin are not consistent with aggrading only in nonbuffered meteoric waters during eogenesis. Consequently, the $\delta^{13} \mathrm{C}$ values indicate that, even if mineralogical stabilization was enhanced by nonbuffered meteoric waters below surfaces of subaerial exposure, aggradation and poronecrosis acted mainly in a deep confined meteoric aquifer during burial or telogenesis. Compaction and/or input of carbonate ions from an external source are required to generate a tight coalescent mosaic texture (Steinen 1978). 


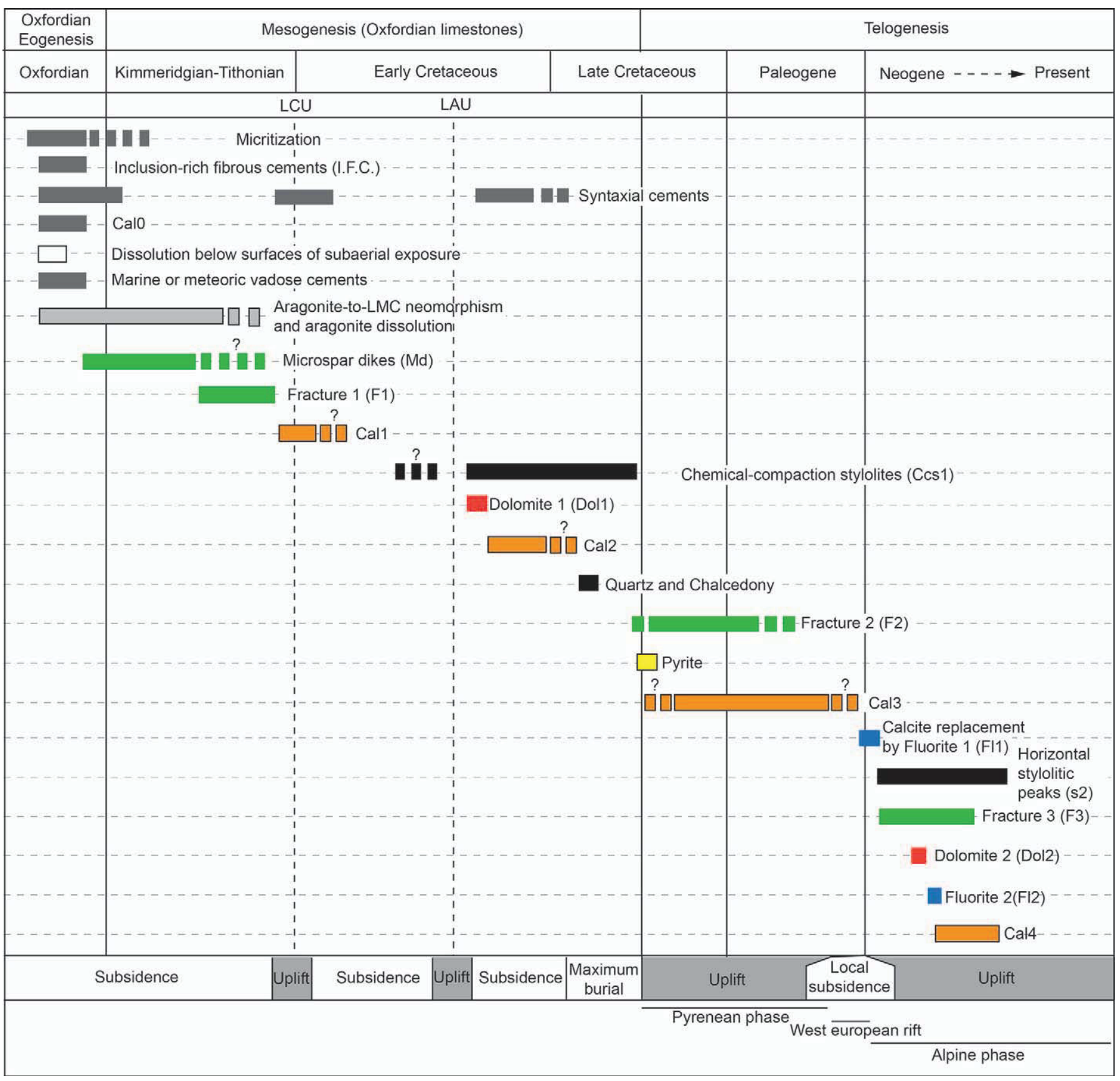

FIG. 12.-General-paragenesis of Oxfordian limestones in the eastern Paris Basin (from Carpentier et al. 2014).

Aggradation and cementation of micrite can operate under a low water/ rock ratio in closed systems oversaturated with respect to calcite (Moshier 1989b). Such kinds of environments are confined phreatic meteoric aquifers or mesogenetic zones.

\section{Impact of Burial Chemical Compaction and Telogenetic Fluids}

LPFs with a micritic matrix distant of subaerial exposure surfaces display typical features of chemical compaction that are illustrated by the extent of stylolitization (Fig. 17). Early cementation is considered as preventing the impact of chemical compaction during burial (Budd 2001; Wallace et al. 2002; Heydari 2003; Croizé et al. 2010). Consequently, early cementation and chemical compaction are generally negatively correlated.
Such a relation is valid for the granular facies of the studied Oxfordian limestones. In contrast, in micrites the extent of cementation, which developed during early mineralogical stabilization, was too limited to counterbalance chemical compaction. However, HPFs were less impacted by pressure solution. This discrepancy is certainly linked to the original clay content of the sediments. Indeed, pre-existing anisotropies can promote the appearance of stylolites (Bathurst 1987), and clay minerals in limestones act as a catalyst for chemical compaction (Aharonov and Katsman 2009). Carpentier et al. (2014) showed that Oxfordian facies affected by chemical compaction correspond to limestones enriched in clay minerals. This can be best appreciated in the nonporous and strongly compacted Calcaires de Dainville Member, where clay interbeds are 

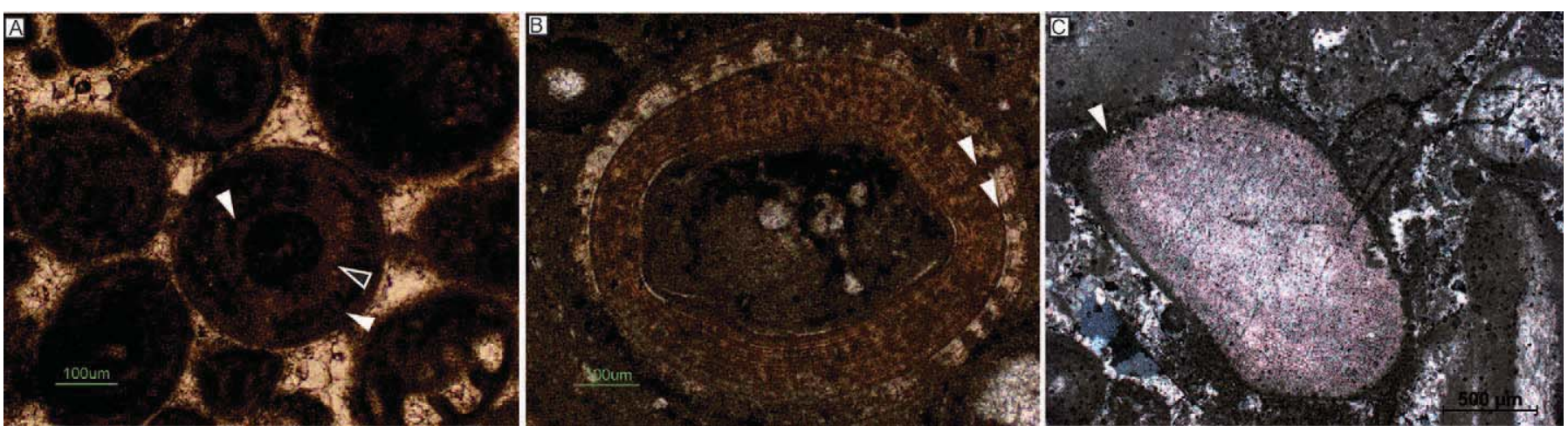

FIG. 13.-Micritization-features of main allochems in Oxfordian limestone. A) Pervasive micritization of ooids. Note the cloudy distribution of micritization and remains of the concentric (white arrows) and radial structures (black arrow) of the cortex (sample PPA 1124, Calcaires crayeux de Maxey Member, EST 204 drill core, plane-polarized light). B) Peripheral micritization of the cortex of an ooid. Micitization is controlled by the location of microborings (arrows) (sample PPA 1096, EST 204 drill core, lower part of the Oolithe de Saucourt Member, plane-polarized light). C) Peripheral fringe of micritization (arrow) on a monocrystalline echinoid clast (sample 25189, EST 205 drill core, Calcaires coralliens de Sorcy Member, cross-polarized light).

common at the top of metric parasequences (Carpentier et al. 2010). Consequently, the amount of early cements in grainstones combined with the clay percentage in lime muds most likely controlled the vertical distribution of chemical compaction in the studied Oxfordian limestones. Chemical compaction provided $\mathrm{Ca}^{2+}$ and $\mathrm{CO}_{3}{ }^{2-}$ to the interstitial waters and favored cementation (Carpentier et al. 2014). During burial, pore fluids consisted of mixed water undersaturated with respect to calcite (Carpentier et al. 2014). Inputs of meteoric waters in deep aquifers which occurred during exposure of the basin margins during the LCU and LAU unconformities (Carpentier et al. 2014; Brigaud et al. 2009; Vincent et al. 2007) certainly favored the micrite aggradation by Ostwald ripening during burial. This timing for the main growth stages of micrites is consistent with the isotopic values of the micrites and with precipitation from mixed meteoric and marine waters during burial. Increased aggradation is attested by the large sizes of euhedral crystals in LPFs (4 to $8 \mu \mathrm{m}$ ). In the Calcaires de Dainville Member, pore sizes were probably reduced early by enhanced cementation during mineralogical stabilization below surfaces of subaerial exposure. As a consequence, subsequent chemical compaction and increased aggradation during burial were sufficient to generate the final closure of porosity. Chemical compaction also operated at the microscopic scale, as evidenced by the crenulated contacts between micrite crystals. Consequently, as shown by the petrophysical data (Fig. 10A), facies containing a micrite matrix and impacted by chemical compaction are less porous and less permeable. In HPFs, poronecrosis in micrites was probably reduced during burial because of the limited chemical compaction and because of the limited percolation of fluids in the micrite matrix. During telogenesis, tension gashes generated new fluid pathways, which allowed inputs of meteoric waters into the micrites of HPFs (Carpentier et al. 2014). The micrite morphotypes suggest that the renewal of these fluids undersaturated with respect to calcite dissolved and smoothed the micrite crystals in the vicinity of fractures. Away from tension gashes, the gradual saturation of fluids due to the dissolution of micrites allowed the pursuance of Ostwald ripening and aggrading of larger micrite crystals. In LPFs, these telogenetic fluids did not significantly impact the micrites, probably because of the low permeability acquired during burial. This reduced impact of meteoric telogenetic fluids and the important contribution of marine host rocks during chemical compaction in LPFs can explain the absence of the covariant trend of $\delta^{18} \mathrm{O}$ and $\delta^{13} \mathrm{O}$ such as observed in HPFs.

\section{Lateral and Vertical Variations in Porosity}

In HPFs, the micritic matrix, peloids, and strongly micritized grains were responsible for the development of microporosity and permeability. In contrast, LPFs consist of coalescent micritic matrix or grainstones in which the quantity of slightly micritized oncoids and echinoid spines is

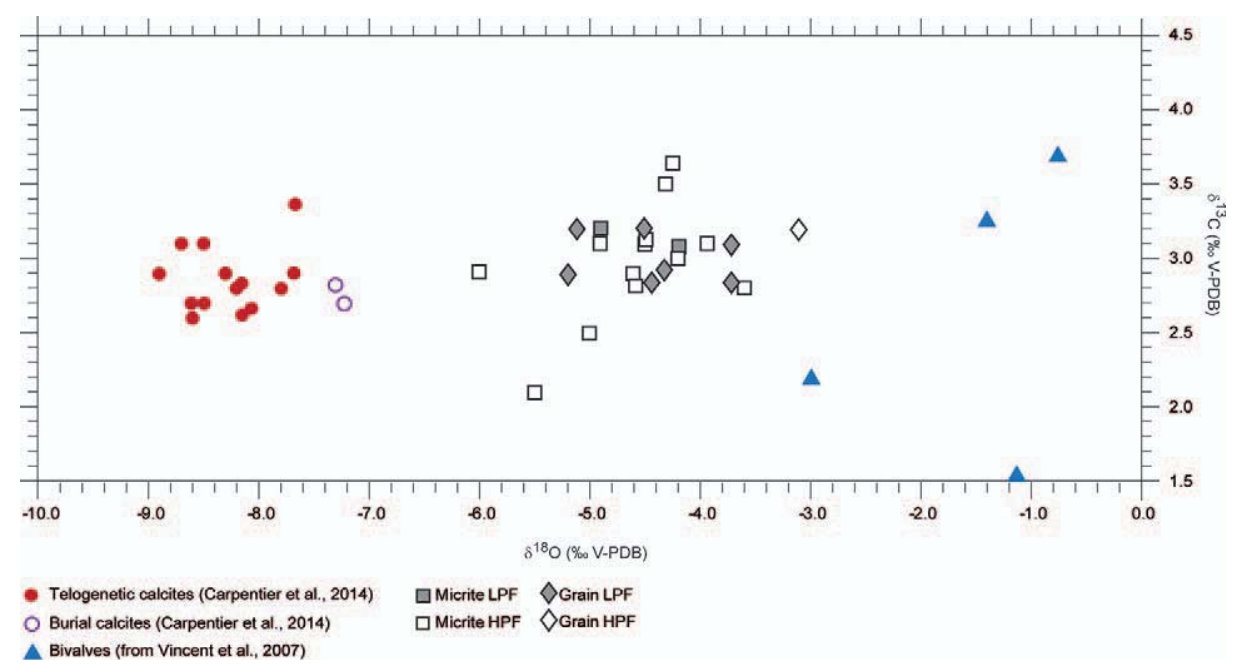

FIG. 14.-Cross-plot- of $\delta^{18} \mathrm{O}$ and $\delta{ }^{13} \mathrm{C}$ values (\% V-PDB) of micrites, bivalves, and blocky calcites in HPFs and LPFs. Values from bivalve shells correspond to values measured by Vincent et al. (2007). Mesogenetic and telogenetic blocky calcites were measured by Carpentier et al. (2014). 
TABLE 2.-Values of $\delta^{18} O \%$ (V-PDB) of calcites using the oxygen isotope fractionation equation between calcite and water (OMNeil 1969) according to the original compositions and temperatures of fluids. Seawater, meteoric waters, and brackish waters had $\delta^{18} O$ values of $0 \%,-4 \%$, and -2 $\%$ respectively ( $V$-SMOW). Temperatures of $22^{\circ} \mathrm{C}$ and $45^{\circ} \mathrm{C}$ correspond to the mean sea-surface temperatures and to the maximal temperature reached during burial of the basin respectively.

\begin{tabular}{lccc}
\hline \hline $\mathrm{T}\left({ }^{\circ} \mathrm{C}\right)$ & $\delta^{18} \mathrm{O}_{\text {water }}(\mathrm{SMOW}) \%$ & $\delta^{18} \mathrm{O}_{\text {calcite }}(\mathrm{SMOW}) \%$ & $\delta^{18} \mathrm{O}_{\text {calcite }}(\mathrm{PDB}) \% 0$ \\
\hline 22.0 & 0.0 & 28.6 & -2.3 \\
22.0 & -2.0 & 26.6 & -4.2 \\
22.0 & -4.0 & 24.6 & -6.1 \\
45.0 & 0.0 & 24.1 & -6.6 \\
45.0 & -2.0 & 22.1 & -8.5 \\
45.0 & -4.0 & 20.1 & -10.5 \\
\hline
\end{tabular}

larger than in HPFs. The total filling of primary porosity in grainstones prevents the connectivity of intragranular micropores. Samples of HPFs from Pagny-sur-Meuse (Pag samples in Fig. 10A) and Maxey-sur-Vaise (Max samples) are characterized by the highest porosity values when compared to their lateral equivalents of the Andra site (samples PPA and 25181 to 25232; Fig. 13A). Also, the EST 422 well, located $10 \mathrm{~km}$ north of the Andra site, is characterized by a merging of middle Oxfordian HPFs. Two main causes allow an explaination of these variations:

The intensity of micritization was certainly facies-controlled by the Oxfordian paleogeography. HPFs preferentially correspond to protected lagoonal environments with peloidal muds and to washover deposits with allochems (ooids, oncoids, bioclasts) incorporated in a micritic matrix. During the middle and late Oxfordian, the platform margin was located southwest of the Andra site in the area of the Marne Valley (Carpentier et al. 2010) (Fig. 2). Limestones of the Pagny-sur-Meuse and Maxey-surMeuse quarries were deposited in internal lagoonal environments. In modern tropical carbonate settings such as the Bahamas platform, micritization is most abundant in protected lagoons (Bathurst 1966, 1971; Scoffin 1970; Lasemi and Sandberg 1984; Reid et al. 1992; Reid and Macintyre 1998). Micritic peloids and carbonate mud are the main facies

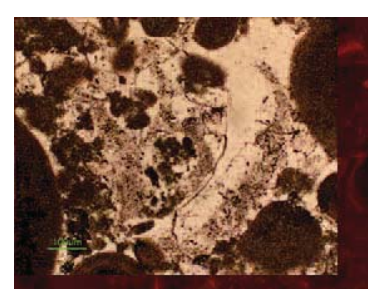

P

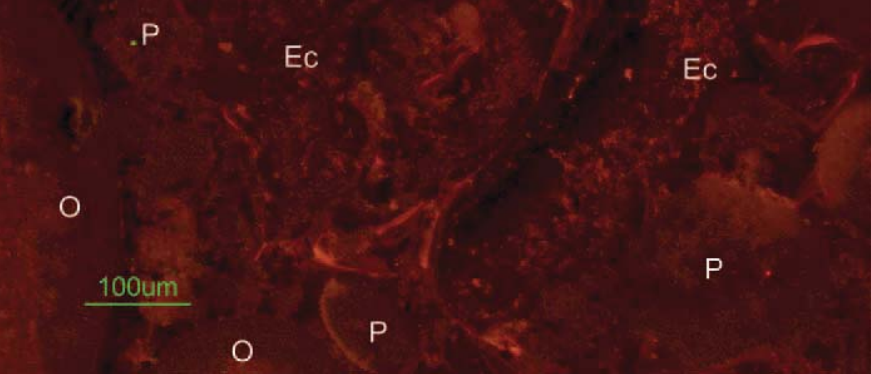

FIG. 15.-Cathodoluminescence-image of a syntaxial cement (Sy) on an echinoid clast $(\mathrm{Ec})$. The first stage of the syntaxial cement is nonluminescent, suggesting precipitation in an open oxidizing environment $(\mathrm{O}$, micritized ooid; $\mathrm{P}$, peloid).
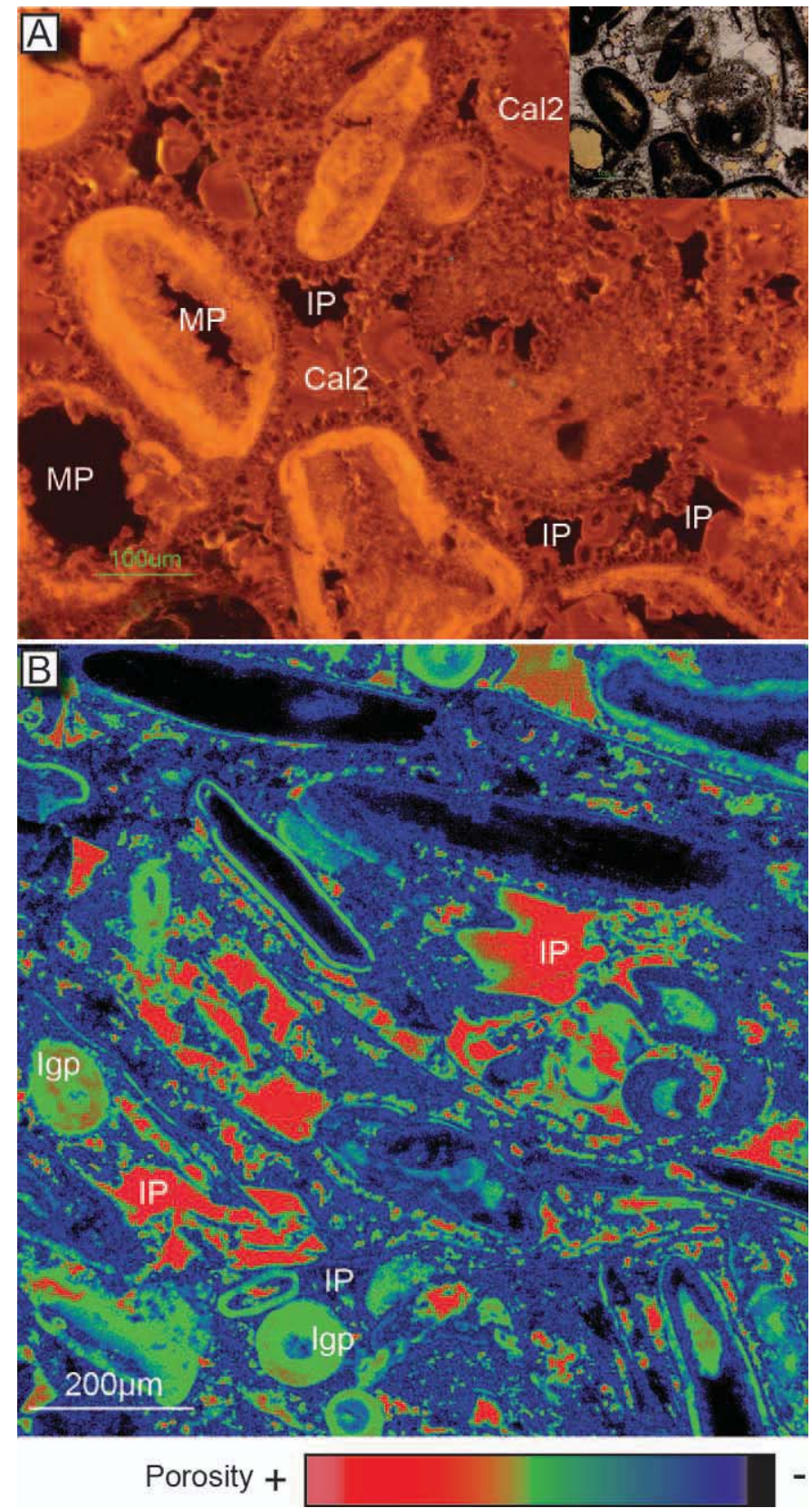

FIG. 16.-Distribution-of porosity in sample Pag 40. A) Macroporosity corresponds to both intergranular (IP) and moldic porosity (MP). The latter is due to dissolution below a surface of subaerial exposure. Residual intergranular porosity is linked to an incomplete cementation by blocky calcite Cal2 (cathodoluminescence). B) Confocal imaging showing the occurrence of intragranular microporosity (Igp) (IP, intergranular porosity).

of such protected lagoons (Bathurst 1971). Facies of the EST204 and EST205 cores were deposited in a more external environment behind the platform margin where granular facies were abundant and diversified (bioclasts, oncoids, reworked ooids) and where lime mud was flushed away.

Recent percolation of meteoric fluids undersaturated with respect to calcite through outcropping Oxfordian carbonates might have slightly enhanced microporosity. At the Andra site, HPFs are actually flooded by groundwater infiltrated from lateral recharge zones. In these aquifers, located between 160 and $360 \mathrm{~m}$ deep, percolating waters are in chemical 


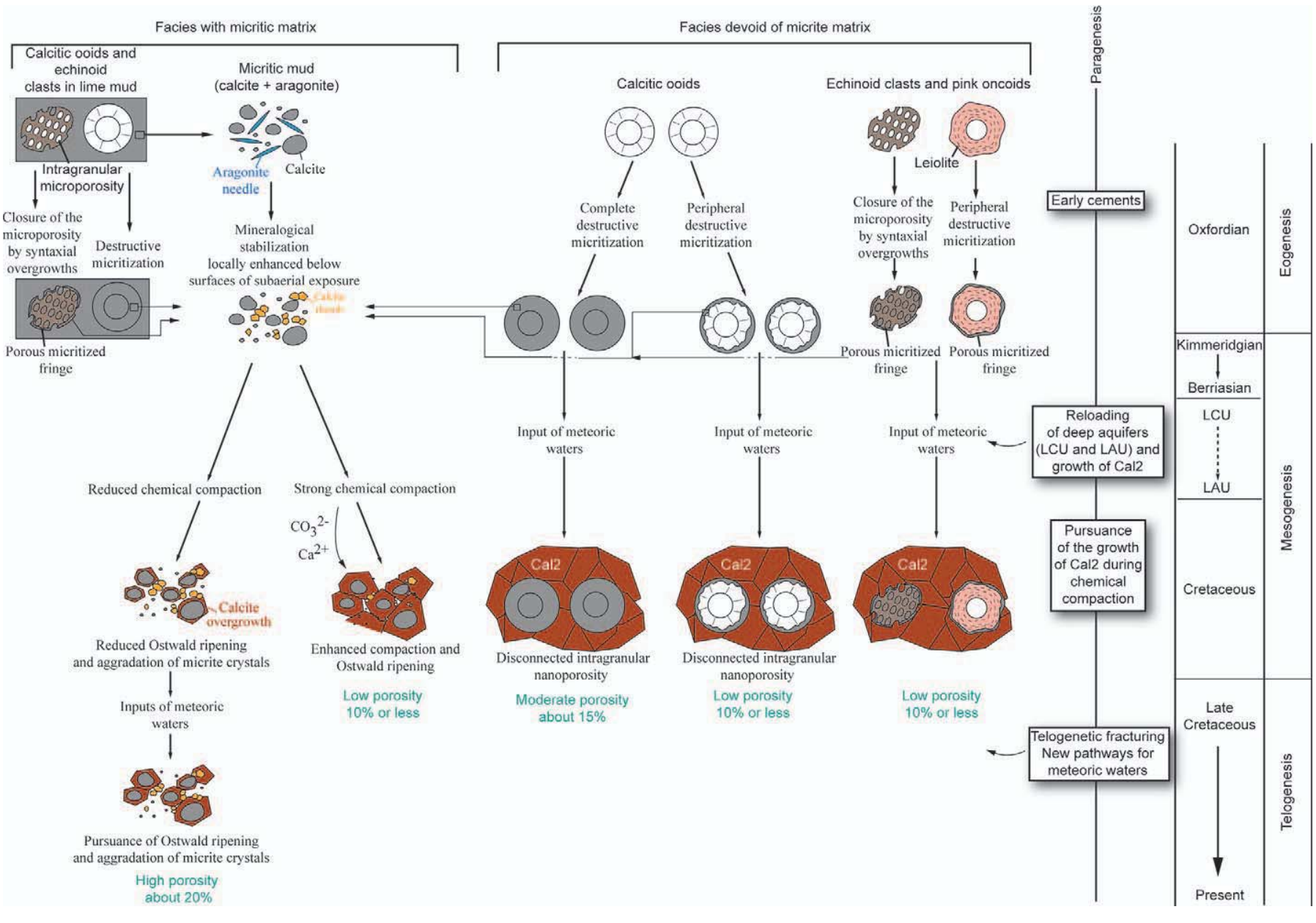

FIG. 18. - General-model of porosity evolution in the Oxfordian limestones of the eastern Paris Basin. For explanation refer to text.

balance with the surrounding rocks. Consequently, recent dissolution certainly is less important in the subsurface than at the outcrop, where freshwater is in direct contact with $\mathrm{CO}_{2}$ reservoirs, such as soils.

In the EST204 drill core, HPFs occur in lagoonal mudstones located in the upper parts of parasequences while granular facies of the lower part are less porous (Fig. 3). This distribution of porous layers explains the vertical discontinuity of some HPFs (e.g., Calcaires crayeux de Maxey Formation). In the sequence-stratigraphic framework of the middle Oxfordian, HPFs are located in transgressive and highstand deposits (Carpentier et al. 2010) (Fig. 3). During this period, the low terrigenous input was unfavorable to the deposition of clays as well as the supply of nutrients. The low ratio of clays prevented the subsequent appearance of intense stylolitization. The proliferation of oncoids with a dense leolitic texture and echinoid spines in the nonporous facies during end of the middle Oxfordian and the late Oxfordian occurred in shallow subtidal environments where siliciclastic and nutrient input increased (Carpentier et al. 2010). More mesotrophic and cooler environments, as envisioned for this time interval (Olivier et al. 2004; Carpentier et al. 2010), favored the proliferation of microbial coatings (oncoids) and grazing organisms such as sea urchins (Hallock 1988; Mutti and Hallock 2003).

\section{General Model}

Destructive micritization was significant in ooids redeposited in lime muds of calm inner lagoonal environments. This process generated the appearance of rounded micrites and an early secondary porosity (Fig. 18). Due to the early precipitation of monocrystalline syntaxial cements in echinoid clasts and due to the dense texture of leolitic oncoids, these particles were only superficially impacted (Fig. 18).

On the sea floor and during shallow burial, early mineralogical stabilization generated the dissolution of aragonitic particles and precipitation of calcite rhombs between diagenetically stable calcitic elements. This process was probably enhanced below surfaces of subaerial exposure in both lime muds and micritic or micritized grains. During burial, characterized by the recharge of deep aquifers (LCU and LAU unconformities) by meteoric waters, Ostwald ripening led to the

FIG. 17.-Vertical-distribution of subaerial exposure surfaces, intensity of chemical compaction (stylolites), porosity, and micritization along the cores EST204 and EST205. Primary facies and texture are the main controls on porosity. Note the decrease in porosity below surfaces of subaerial exposure for the facies containing a micritic matrix. 
dissolution of the smallest micrite crystals and to aggradation of the largest particles. Aggradation was enhanced in LPFs by inputs of water enriched in carbonate and calcium ions through chemical compaction. These overgrowths led to the formation of coalescent micrites and microscopic pressure-solution contacts between micrite crystals. Telogenetic fracturing permitted new inputs of meteoric waters and the pursuance of Ostwald ripening in HPFs. In contrast, the low permeability in micrites compacted and cemented during burial in LPFs prevented any impact of telogenetic fluids. Intergranular porosity in grainstones was filled by burial calcites (Cal2), and intragranular microporosity was disconnected. Finally, facies with a muddy matrix, not impacted by early meteoric diagenesis below surfaces of subaerial exposure and poorly affected by chemical compaction, have porosities at about $20 \%$.

These results show that, contrary to the commonly accepted idea, early meteoric diagenesis during periods of subaerial exposure does not always generate microporous micrites. Instead, as also envisioned by Leonide et al. (2014) in lagoonal muds of the Barremian-Aptian in southeastern France, early exposure favors abundant cementation and poronecrosis. Early cementation of muds does not seem to be efficient enough to counterbalance compaction during burial. However, our results show that in addition to primary mineralogy, mesogenesis and telogenesis are important controlling processes. Input of waters undersaturated with respect to calcite in deep aquifers during burial appears to be the main controlling factor for enhancing aggrading neomorphism and favoring the appearance of microporous micrites. Exposures on basin margins constitute the most favorable contexts to reload these aquifers with meteoric waters. Therefore, such events must be identified to predict possible occurrence of microporous facies. Another important parameter concerns the occurrence of heterogeneities favoring pressure solution, which must be evaluated to refine predictions on petrophysical properties of micritic limestones. The next step in understanding micrite diagenesis is to use an experimental approach. Simulation of early diagenesis on modern lime muds with various fluid and sediment compositions and subsequent simulation of burial diagenesis under stress, as recently performed by Neveux et al. (2014a, 2014b), will allow better constraints for the chemical and geomechanical controls on the textural and petrophysical evolution of micrites.

\section{CONCLUSIONS}

In the Oxfordian limestones of the eastern Paris Basin the porosity is mainly microscopic. The vertical compartmentalization of HPFs is controlled by the vertical changes of facies in parasequences that tend to diminish their reservoir quality. Several factors controlled the preservation or creation of microporosity:

- Destructive micritization of carbonate grains favored the appearance of early secondary microporosity. The intensity of micritization was controlled by the paleoenvironmental distribution of facies on the carbonate platform. Inner lagoonal facies were more strongly micritized than external platform facies.

- Leiolitic oncoids and echinoid clasts are only faintly porous or tight because of their dense leolitic or monocrystalline structure, respectively, which prevented intensive micritization.

- Infiltrations of meteoric water below surfaces of subaerial exposure may have favored the mineralogical stabilization process and the enhancement of early poronecrosis.

- The intensity of early mineralogical stabilization and Ostwald ripening in micrites during burial controlled the preservation or the closure of the porous network between grains, while burial calcite cementation of intergranular porosity in grainstones closed the connections between microporous grains.
- Chemical compaction favored the aggradation of micrite crystals during Ostwald ripening and generated tight coalescent micrites.

As in other recent studies, the present work shows that meteoric diagenesis below early exposure surfaces are not systematically responsible for porogenesis in micrite but on the contrary may lead to tight mudstones. The understanding of diagenesis in micrites must be considered from the angle not only of eogenesis but also of mesogenetic and telogenetic process. Inputs of undersaturated waters in deep aquifers are certainly most efficient to preserve or generate large volumes of microporous limestones.

\section{ACKNOWLEDGMENTS}

We are grateful to Andra for supporting this study. We want to thank the CARMEUSE and MEAC companies for allowing us to access to the Pagny-sur-Meuse and Maxey-sur-Vaise quarries. The Région Lorraine is warmly thanked for financially supporting the UMR GeoRessources within the framework of the project PRST-SGE "Transferts en milieu géologique." We are grateful to Jerôme Sterpenich for his help with the mapping of porosity. We also thank the anonymous reviewers and Associate Editor Stacy Lynn Reeder, who greatly contributed to improve the manuscript.

\section{REFERENCES}

Aharonov, E., and Katsman, R., 2009, Interaction between pressure solution and clays in stylolite development: insights from modelling: American Journal of Science, v. 309 , p. 607-632.

André, G., Hibsch, C., Beaudoin, B., Carpentier, C., Fourcade, S., Cathelineau, M., and Elion, P., 2004, Filons sédimentaires oxfordiens: implications tectoniques et diagénétiques pour l'Est du Bassin de Paris: Société Géologique de France, Bulletin, v. 175 , p. $595-605$

André, G., Hibsch, C., Fourcade, S., Cathelineau, M., and Buschaert, S., 2010 Chronology of fracture sealing under a meteoric fluid environment: microtectonic and isotopic evidence of major Cainozoic events in the eastern Paris Basin (France): Tectonophysics, v. 490, p. 214-228.

BathuRst, R.G.C., 1966, Boring algae, micrite envelopes and lithification of molluscan biosparites: Geological Journal, v. 5, p. 15-32.

Bathurst, R.G.C., 1971, Carbonate Sediments and Their Diagenesis: Amsterdam, Elsevier, 658 p.

BathuRst, R.G.C., 1987, Diagenetically enhanced bedding in argillaceous platform limestones: stratified cementation and selective compaction: Sedimentology, v. 34, p. 749-778.

Blaise, T., Barbarand, J., Kars, M., Ploquin, F., Aubourg, C., Brigaud, B., Cathelineau, M., El Albani, A., Gautheron, C., Izart, A., Janots, D., Michels, R., Pagel, M., Pozzi, J.-P., Borron, M.-C., And Landrein, P., 2014, Reconstruction of low temperature $\left(<100^{\circ} \mathrm{C}\right)$ burial in sedimentary basins: a comparison of geothermometer in the intracontinental Paris Basin: Marine and Petroleum Geology, v. 53, p. $71-87$.

Braga, J.C., Martin, J.M., And Riding, R., 1995, Controls on microbial dome fabric development along a carbonate-siliciclastic shelf-basin transect, Miocene, SE Spain: Palaios, v. 10, p. 347-361.

Brigaud, B., Pucéat, E., Pellenard, P., Vincent, B., and Joachimski, M., 2008, Climatic fluctuations and seasonality during the Late Jurassic (Oxfordian-Early Kimmeridgian) inferred from $\delta^{18} \mathrm{O}$ of Paris Basin oyster shells: Earth and Planetary Science Letters, v. 273 , p. $58-67$.

Brigaud, B., Durlet, C., Deconinck, J.F., Vincent, B., Thierry, J., And Trouiller, A., 2009, The origin and timing of multiphase cementation in carbonates: impact of regional scale geodynamic events on the Middle Jurassic Limestone diagenesis (Paris Basin, France): Sedimentary Geology, v. 222, p. 161-180.

BudD, D.A., 1989, Micro-rhombic calcite and microporosity in limestones: a geochemical study of the Lower Cretaceous Thamama Group, U.A.E.: Sedimentary Geology, v. 63, p. 293-311.

BudD, D.A., 2001, Permeability loss with depth in the Cenozoic carbonate platform of west-central Florida: American Association of Petroleum Geologists, Bulletin, v.85, p. $1253-1272$.

Carpentier, C., Martin-Garin, B., Lathuilière, B., and Ferry, S., 2006, Correlation of reefal Oxfordian episodes and climatic implications in the eastern Paris Basin (France): Terra Nova, v. 18, p. 191-201.

Carpentier, C., Lathuilieke, B., and Ferry, S., 2010, Sequential and climatic framework of the growth and demise of a carbonate platform: implications for the peritidal cycles (Late Jurassic, north-eastern France): Sedimentology, v. 57, p. 985 1020 . 
Carpentier, C., Brigaud, B., Blaise, T., Vincent, B., Durlet, C., Boulvais, P., Pagel, M., Hibsch, C., Yven, B., Lach, P. Cathelineau, M. Borron, M.C., Landrein, P., AND Buschaert, S., 2014, Impact of basin burial and exhumation on Jurassic carbonates diagenesis on both sides of a thick clay barrier (Paris Basin, NE France): Marine and Petroleum Geology, v. 53, p. 44-70.

Cavallo, L., and Smosna, R., 1997, Predicting porosity distribution within oolitic tidal bars, in Kupecz, J.A., Gluyas, J.G., and Bloch, S., eds., Reservoir Quality Prediction in Sandstones and Carbonates: American Association of Petroleum Geologists, Memoir 69, p. 211-229.

Chafetz, H.S., AND Buczynski, C., 1992, Bacterially induced lithification of microbial mats: Palaios, v. 7, p. $277-293$

Choquette, P.W., And Steinen, R.P., 1980, Mississipian non-supratidal dolomite, Illinois Basin: evidences for mixed-water dolomitization, in Zenger, D.H., Dunham, J.B., and Ethington, R.L., eds., Concepts and Models of Dolomitization: SEPM, Special Publication 28, p. 163-196

Clauer, N., O’Neil, J.R., and Furlan, S., 1995, Clay minerals as records of temperature conditions and duration of thermal anomalies in the Paris Basin, France: Clay Minerals, v. 30, p. 1-13.

Croizé, D., Ehrenberg, S.N., Buørlykke, K., Renard, F., and Jahren, J., 2010, Petrophysical properties of bioclastic platform carbonates: implications for porosity controls during burial: Marine and Petroleum Geology, v. 27, p. 1765-1774.

Da Silva, A.C., Loisy, C., Cerepi, A., Toullec, R., Kiefer, E., Humbert, L., And RAzIN, P., 2009, Variations in stratigraphic and reservoir properties adjacent to the mid-Paleocene sequence boundary, Campo section, Pyrenees, Spain: Sedimentary Geology, v. 219, p. 237-251

De-Graciansky, P.C., and Jacquin, T., 2003, Evolution des structures et de la paléogéographie au passage Lias-Dogger dans le Bassin de Paris d'après les données de la subsurface: Société Géologique de France, Bulletin, v. 174, p. 3-17.

Derby, J.R., AND Kilpatrick, J.T., 1985, Ordovician Red River dolomite reservoirs, Killdeer Field, North Dakota, in Roehl, P.O., and Choquette, P.W., eds., Carbonate Petroleum Reservoirs: Berlin, Springer Verlag, p. 357-367.

Deville De Periere, M., Durlet, C., Vennin, E., Lambert, L., Bourillot, R., Caline, B., AND Poli, E., 2011, Morphometry of micrite particles in Cretaceous microporous limestones of the Middle East: influence on reservoir properties: Marine and Petroleum Geology, v. 28, p. 1727-1750.

Dickson, J.A.D., 1965, A modified staining technique for carbonates in thin sections: Nature, v. 205 , p. 587

Dupraz, C., Reid, R.P., Braissant, O., Decho, A.W., Norman, R.S., and Visscher, P.T., 2009, Processes of carbonate precipitation in modern microbial mats: EarthScience Reviews, v. 96, p. 141-162.

Elie, M. Landais, P. and Fauvel, P., 1999, Cinétique de transformation des biomarqueurs pour la détermination de la paléotempérature maximale des sédiments du Callovo-Oxfordien du site de l'Est [Abstract]: Andra Scientific Sessions, Atlas des Communications par Affiche, v. 1, Nancy 7-9 September 1999.

Fell, H.B., and Pawson, D.L., 1966, Echinacea, in Moore, R.C., ed., Treatise on Invertebrate Paleontology, Part U: University of Kansas Press, Echinodermata 3, p. $367-440$

Ferry, S., AND SchaAf, A., 1981, The Early Cretaceous environment at Deep Sea Drilling Project Site 463 (Mid-Pacific Mountains), with reference to the Vocontian Trough (French Subalpine Ranges), in Thiede, J., and Vallier, T.L., et al., eds., Initial Reports of the Deep Sea Drilling Project, Washington, U.S. Government Printing Office, v. 62, p. 669-682

Ferry, S., Pellenard, P., Collin, P.Y., Thierry, J., Marchand, D., Deconninck, J.F., Robin, C. Carpentier, C. Durlet, C., and Curial, A., 2007, Synthesis of recent stratigraphic data on Bathonian to Oxfordian deposits of the eastern Paris Basin: Société Géologique de France, Bulletin, v. 178, p. 37-57.

Flügel, E., 2004, Microfacies of Carbonate Rocks: Analysis, Interpretation and Application: Berlin, Springer-Verlag, 983 p.

FoLK, R.L., 1965, Some aspects of re-crystallization in ancient limestones, in Pray, L.C., and Murray, R.C., eds., Dolomitization and Limestone Diagenesis: a Symposium: SEPM, Special Publication 13, p. 1448

FoLK, R.L., 1974, The natural history of crystalline calcium carbonate: effect of magnesium content and salinity: Journal of Sedimentary Geology, v. 44, p. 40-53.

Greenlee, S.M., and Lehrmann, P.J., 1993, Stratigraphic framework of productive carbonate build-ups, in Loucks, R.G., and Sarg, J.F., eds., Carbonate sequence stratigraphy; recent developments and applications: American Association of Petroleum Geologists, Memoir 57, p. 43-62.

Guillocheau, F., Robin, C., Allemand, P., Bourquin, S., Brault, N., Dromart, G., Friedenderg, R., Garcia, J.P., Gaulier, J.M., Gaumet, F., Grosdoy, B., Hanot, F., Le-Strat, P., Mettraux, M., Nalpas, T., Prijac, C., Rigollet, C., Serrano, O., and Grandjean, G., 2000, Meso-Cenozoic geodynamic evolution of the Paris Basin: 3D stratigraphic constraints: Geodinamica Acta, v. 13, p. 189-246.

Hairabian, A., Fournier, F., Borgomano, J., and Nardon, S., 2013, Propriétés pétrophysiques des carbonates resédimentés en milieu marin profond: les affleurements d'âge Crétacé Supérieur du Gargano (SE Italie) [Abstract]: Book of the 14ieme Congrès français de sédimentologie, ASF, Paris, November 2013, p. 190.

Hallock, P., 1988, The role of nutrient availability in bioerosion: consequences to carbonate build-ups: Palaeogeography, Palaeoclimatology, Palaeoecology, v. 63, p. $275-291$.

HeYdari, E., 2003, Meteoric versus burial control on porosity evolution of the Smackover Formation: American Association of Petroleum Geologists, Bulletin, v. 87 , p. $1779-1797$.
Hillgärtner, H., Dupraz, C., and Hug, W., 2001, Microbially induced cementation of carbonate sands: are micritic meniscus cements good indicators of vadose diagenesis? Sedimentology, v. 48, p. 117-132.

Jobard, E., Sterpenich, J., Pironon, J., Corvisier, J., Jouanny, M., and Randi, A., 2013, Experimental simulation of the impact of a thermal gradient during geological sequestration of $\mathrm{CO}_{2}$ : The COTAGES experiment: International Journal of Greenhouse Gas Control, v. 12, p. 56-71.

Kenter, J.A.M., Harris, P.M., Collins, J.F., Weber, L.J., Kuanysheva, G., and FisCHER, D.J., 2006, Late Visean to Bashkirian platform cyclicity in the central Tengiz buildup, Precaspian Basin, Kazakhstan: depositional evolution and reservoir development, in Harris, P.M., and Weber, L.J., eds., Giant Hydrocarbon Reservoirs of the World: from Rocks to Reservoir Characterization and Modeling: American Association of Petroleum Geologists, Memoir 88, p. 7-54

Kiessling, W., Flügel, E., and GolonKa, J., 1999, Paleoreef maps: evaluation of a comprehensive database on Phanerozoic reefs: American Association of Petroleum Geologists, Bulletin, v. 83, p. 1552-1587.

Lachniet, M.S., And Patterson, W.P., 2009, Oxygen isotope values of precipitation and surface waters in northern Central America (Belize and Guatemala) are dominated by temperature and amount effects: Earth and Planetary Science Letters, v. 284, p. 435-446.

Lambert, L., Durlet, C., Loreau, J.P., and Marnier, G., 2006, Burial dissolution of micrite in Middle East carbonate reservoirs (Jurassic-Cretaceous): keys for recognition and timing: Marine and Petroleum Geology, v. 23, p. 79-92.

Lasemi, Z., And SandBerg, P.A., 1984, Transformation of aragonite-dominated lime muds to microcrystalline limestones: Geology, v. 12, p. 420-423.

Lecuyer, C., Picard, S., Garcia, J.-P., Sheppard, S.M.F., Grandjean, P., and Dromart, G., 2003, Thermal evolution of Tethyan surface waters during the Middle-Late Jurassic: Evidence from $\delta^{18} \mathrm{O}$ values of marine fish teeth: Paleoceanography, v. 8, p. 21-41.

Léonide, P., Fournier, F., Reijmer, J.J.G., Vonhof, H., Borgomano, J., Dijk, J., Rosenthal, M., van Goethem, M., Cochard, J., and Meulenaars, K., 2014, Diagenetic patterns and pore space distribution along a platform to outer-shelf transect (Urgonian limestone, Barremian-Aptian, SE France): Sedimentary Geology, v. 306, p. $1-23$.

Lefort, A., Lathuilière, B., Carpentier, C., and Huault, V., 2011, Microfossil assemblages and relative sea-level fluctuations in a lagoon at the Oxfordian/ Kimmeridgian boundary (Upper Jurassic) in the eastern part of the Paris Basin: Facies, v. 57, p. 649-662.

LoREAU, J.P., 1982, Sediments aragonitiques et leur genèse: Muséum d'Histoire Naturelle Memoir, v. 47, 312 p.

Maliva, R.G., Missimer, T.M., And Dickson, J.A.D., 2000, Skeletal aragonite neomorphism in Plio-Pleistocene sandy limestones and sandstones, Hollywood, Florida, USA: Sedimentary Geology, v. 136, p. 147-154.

McQuillan, H., 1985, Fracture-controlled production from the Oligo-Miocene Asmar Formation in Gachsaran and Bibi Hakimeh Fields, Southwest Iran, in Roehl, P.O., and Choquette, P.W., eds., Carbonate Petroleum Reservoirs: Berlin, Springer Verlag, p. 513-523.

Melim, L.A., Westphal, H., Swart, P.K., Eberli, G.P., and Munnecke, A., 2002, Questioning carbonate diagenetic paradigms: evidence from the Neogene of the Bahamas: Marine Geology, v. 185, p. 27-53.

Moshier, O.S., 1989a, Microporosity in micritic limestones: a review: Sedimentary Geology, v. 63, p. 191-213.

MoshIER, O.S., 1989b, Development of microporosity in a micritic limestone reservoir Lower Cretaceous, Middle East: Sedimentary Geology, v. 63, p. 217-240.

MutTI, M., 2000, Microbial origin of microcrystalline carbonate sediment and cements filling fractures in basalts recovered at site 1001, Caribbean sea, in Leckie, R.M., Sigurdsson, H., Acton, G.D., and Draper, G., eds., Proceedings of the Ocean Drilling Program, Scientific Results, v. 165, p. 227-232.

Mutti, M., AND Hallock, P., 2003, Carbonate systems along nutrient and temperature gradients: some sedimentological and geochemical constraints: International Journal of Earth Sciences, v. 92, p. 465-475.

Neveux, L., Grgic, D., Carpentier, C., Pironon, J., and Girard, J.P., 2014a, Influence of hydrocarbon injection on the compaction by pressure solution of a carbonate rock: an experimental study under triaxial stresses: Marine and Petroleum Geology, v. 55 , p. $282-294$.

Neveux, L., Grgic, D., Carpentier, C., Pironon, J., Truche, L., and Girard, J.P., 2014b, Experimental simulation of chemomechanical processes during deep burial diagenesis of carbonate rocks: Journal of Geophysical Research, Solid Earth, v. 119, p. 1-24.

Olivier, N., Carpentier, C., Martin-Garin, B., Lathuilière, B., Gaillard, C., Ferry, S., Hantzpergue, P., and Geister, J., 2004, Coral-microbialite reefs in pure carbonate versus mixed carbonate-siliciclastic depositional environments: the example of the Pagny-sur-Meuse section (Upper Jurassic, northeastern France) Facies, v. 50, p. 229-255.

O’Neil, J.R., Clayton, R.N., and Mayeda, T.K., 1969, Oxygen isotope fractionation in divalent metal carbonates: Journal of Chemical Physics, v. 51, p. 5547-5558.

Ostwald, W., 1887, Lehrbuch der allgemeinen Chemie, 2: Leipzig, Verlag von Wilhelm Engelmann.

Palmer, T., Hudson, J., and Wilson, M., 1988, Palaeoecolgical evidence for early aragonitic dissolution in ancient calcite seas: Nature, v. 335, p. 809-810.

Pucéat, E., Lécuyer, C., Sheppard, S.M.F., Dromart, G., Reboulet, S., and Grandiean, P., 2003, Thermal evolution of Cretaceous Tethyan marine water inferred from oxygen isotope composition of fish tooth enamels: Paleoceanography, v. 18 , p. 1029-1040. 
Rabier, C., Anguy, Y., Cabioch, G., and Genthon, P., 2008, Characterization of various stages of calcitization in Porites sp corals from uplifted reefs: case studies from New Caledonia, Vanuatu, and Futuna (South-West Pacific): Sedimentary Geology, v. 211 , p. $73-86$.

Reid, P.R., And Macintyre, I.G., 1998, Carbonate recrystallization in shallow marine environments: a widespread diagenetic process forming micritized grains: Journal of Sedimentary Research, v. 68, p. 928-946.

Reid, P.R., AND Macintyre, I.G., 2000, Microboring versus recrystallization: further insight into the micritization process: Journal of Sedimentary Research, v. 70, p. 24-28.

Reid, P.R., Macintyre, I.G., and Post, J.E., 1992, Micritized skeletal grains in a northern Belize lagoon: a major source of Mg-calcite mud: Journal of Sedimentary Petrology, v. 62, p. 145-156.

Richard, J., Sizun, J.P., AND MachHour, L., 2007, Development and compartmentalization of chalky carbonate reservoirs: the Urgonian Jura-Bas Dauphine platform model (Genissiat, southeastern France): Sedimentary Geology, v. 198, p. 195-207.

RIES, J., 2005, aragonite production in calcite seas: effects of seawater $\mathrm{Mg} / \mathrm{Ca}$ ratio on the calcification and growth of the calcareous alga Penicillus capitatus: Paleobiology, v. 31, p. $445-458$

Saller, P., And Moore, C.H., 1986, Dolomitization in the Smackover Formation, Escambia County, Alabama: Gulf Coast Association of Geological Societies, Transactions, v. 36, p. 275-282.

Sandberg, P.A., 1983, An oscillating trend in Phanerozoic non-skeletal carbonate mineralogy: Nature, v. 305 , p. 19-22.

Scoffin, T.P., 1970, The trapping and binding of subtidal carbonate sediments by marine vegetation in Bimini Lagoon, Bahamas: Journal of Sedimentary Petrology, v. 40 , p. $249-273$

Steinen, R.P., 1978, On the diagenesis of lime mud: scanning electron microscope observations of subsurface material from Barbados, W.I.: Journal of Sedimentary Petrology, v. 48, p. 1139-1148.

Steinen, R.P., 1982, SEM observations on the replacement of Bahamian aragonitic mud by calcite: Geology, v. 10, p. 78-90.

Sterpenich, J., Sausse, J., Pironon, J., Géhin, A., Hubert, G., Perfetti, E., and Grgic, D., 2009, Experimental ageing of oolitic limestones under $\mathrm{CO}_{2}$ storage conditions. petrographical and chemical evidence: Chemical Geology, v. 265, p. 99-112.
Suarez, M.B., González, L.A., Ludvigson, G.A., Vega, F.J., and Alvarado-Ortega, J., 2009, Isotopic composition of low-latitude paleoprecipitation during the Early Cretaceous: Geological Society of America, Bulletin, v. 121, p. 1584-1595.

Thierry, J., 2000, Early Kimmeridgian (146-144 Ma), in Dercourt, J., Ricou, L.E., and Vrielynck, B., eds., Atlas Peri-Tethys, Explanatory Notes: Paris, Commission de la Carte Géologique du Monde, p. 85-97.

Vincent, B., Emmanuel, L., And Loreau, J.P., 2004, Signification du signal isotopique $\left(\delta^{18} \mathrm{O}, \delta^{13} \mathrm{C}\right)$ des carbonates neritiques: composante diagenetique et composante originelle (Jurassique superieur de l'Est du Bassin de Paris, France): Paris, Comptes Rendus, Academie des Sciences, v. 336, p. 29-39.

Vincent, B., Emmanuel, L., Houel, P., and Loreau, J.P., 2007, Geodynamic control on carbonate diagenesis: petrographic and isotopic investigation of the Upper Jurassic formations of the Paris Basin (France): Sedimentary Geology, v. 197, p. 267-289.

Volery, C., Davaud, E., Foubert, A., and Caline, B., 2009a, Lacustrine microporous micrites of the Madrid Basin (Late Miocene, Spain) as analogues for shallow-marine carbonates of the Mishrif reservoir Formation (Cenomanian to Early Turonian, Middle East): Facies, v. 56, p. 385-397.

Volery, C., Davaud, E., Foubert, A., and Caline, B., 2009b, Shallow-marine microporous carbonate reservoir rocks in the Middle East: relationship with seawater $\mathrm{Mg} / \mathrm{Ca}$ ratio and eustatic sea level: Journal of Petroleum Geology, v. 32, p. $313-325$.

Volerry, C., Davaud, E., Durlet, C., Clavel, B., Charollais, J., and Caline, B., 2010 Microporous and tight limestones in the Urgonian Formation (late Hauterivian to early Aptian) of the French Jura Mountains: focus on the factors controlling the formation of microporous facies: Sedimentary Geology, v. 230, p. 21-34.

Wallace, M.W., Holdgate, G.R., Daniels, J., Gallagher, S.J., and Smith, A., 2002 Sonic velocity, submarine canyons, and burial diagenesis in Oligocene-Holocene coolwater carbonates, Gippsland Basin, southeast Australia: American Association of Petroleum Geologists Bulletin, v. 86, p. 1593-1607.

Ziegler, P. A., 1990, Pangaea Break-up: Jurassic-Early Cretaceous opening of central North Atlantic and western Tethys, in Shell International Petroleum, Maatschappij., ed., Geological Atlas of Western and Central Europe; Second and Completely Revised Edition: London, Geological Society, p. 91-122. 